\title{
Dynamic changes in outlet glaciers in northern Greenland from 1948 to 2015
}

\author{
Emily A. Hill ${ }^{1}$, J. Rachel Carr ${ }^{1}$, Chris R. Stokes ${ }^{2}$, and G. Hilmar Gudmundsson ${ }^{3}$ \\ ${ }^{1}$ School of Geography, Politics, and Sociology, Newcastle University, Newcastle-upon-Tyne, NE1 7RU, UK \\ ${ }^{2}$ Department of Geography, Durham University, Durham, DH1 3LE, UK \\ ${ }^{3}$ Department of Geography and Environmental Sciences, Northumbria University, Newcastle-upon-Tyne, NE1 8ST, UK
}

Correspondence: Emily A. Hill (e.hill3@newcastle.ac.uk)

Received: 19 January 2018 - Discussion started: 9 February 2018

Revised: 22 August 2018 - Accepted: 8 September 2018 - Published: 9 October 2018

\begin{abstract}
The Greenland Ice Sheet (GrIS) is losing mass in response to recent climatic and oceanic warming. Since the mid-1990s, tidewater outlet glaciers across the ice sheet have thinned, retreated, and accelerated, but recent changes in northern Greenland have been comparatively understudied. Consequently, the dynamic response (i.e. changes in surface elevation and velocity) of these outlet glaciers to changes at their termini, particularly calving from floating ice tongues, is poorly constrained. Here we use satellite imagery and historical maps to produce an unprecedented 68-year record of terminus change across 18 major outlet glaciers and combine this with previously published surface elevation and velocity datasets. Overall, recent (1995-2015) retreat rates were higher than at any time in the previous 47 years (since 1948). Despite increased retreat rates from the 1990s, there was distinct variability in dynamic glacier behaviour depending on whether the terminus was grounded or floating. Grounded glaciers accelerated and thinned in response to retreat over the last 2 decades, while most glaciers terminating in ice tongues appeared dynamically insensitive to recent ice tongue retreat and/or total collapse. We also identify glacier geometry (e.g. fjord width, basal topography, and ice tongue confinement) as an important influence on the dynamic adjustment of glaciers to changes at their termini. Recent grounded outlet glacier retreat and ice tongue loss across northern Greenland suggest that the region is undergoing rapid change and could soon contribute substantially to sea level rise via the loss of grounded ice.
\end{abstract}

\section{Introduction}

Mass loss from the Greenland Ice Sheet (GrIS) has accelerated since the early 2000s, compared to the 1970s and 1980s (Kjeldsen et al., 2015; Rignot et al., 2008), and could contribute $0.45-0.82 \mathrm{~m}$ of sea level rise by the end of the $21 \mathrm{st}$ century (Church et al., 2013). Recent mass loss has been attributed to both a negative surface mass balance and increased ice discharge from marine-terminating glaciers (van den Broeke et al., 2016; Enderlin et al., 2014). The latter has contributed $\sim 40 \%$ of total mass loss across the GrIS since 1991 (van den Broeke et al., 2016), and increased mass loss was synchronous with widespread glacier acceleration from 1996 to 2010 (Carr et al., 2017b; Joughin et al., 2010; Moon et al., 2012; Rignot and Kanagaratnam, 2006). Coincident with glacier acceleration, dynamic thinning has occurred at elevations $<2000 \mathrm{~m}$ on fast-flowing marine-terminating outlet glaciers (Abdalati et al., 2001; Krabill et al., 2000), particularly in the southeast and northwest of the GrIS (Csatho et al., 2014; Pritchard et al., 2009). Alongside thinning and acceleration, terminus retreat has been widespread since the 1990s (e.g. Box and Decker, 2011; Carr et al., 2017b; Jensen et al., 2016; Moon and Joughin, 2008), and several studies have identified terminus retreat as a key control on inland ice flow acceleration and dynamic thinning (Howat et al., 2005; Joughin et al., 2004, 2010; Nick et al., 2009; Thomas, 2004; Vieli and Nick, 2011).

Ice-sheet-wide dynamic changes have been linked to 21stcentury atmospheric/ocean warming and the loss of sea ice (e.g. Bevan et al., 2012; Cook et al., 2014; Holland et al., 2008; McFadden et al., 2011; Moon and Joughin, 2008). However, tidewater glaciers can also behave in a cyclic man- 
ner, which is not always directly related to climate forcing (Meier and Post, 1987; Pfeffer, 2007) but instead relates to their fjord geometry (Carr et al., 2013; Enderlin et al., 2013; Howat et al., 2007; Powell, 1990). These glacier cycles are characterised by slow periods of advance (up to centuries) followed by rapid unstable retreat (Meier and Post, 1987; Post, 1975; Post et al., 2011). Once initiated, terminus retreat can initiate dynamic adjustments independent of climate and instead modulated by local outlet glacier geometry and associated resistive stresses. However, differences in the nature of calving and basal/lateral resistive stresses acting at tidewater glaciers with either grounded or floating termini can alter their dynamic response to retreat. Continuous low-magnitude calving events and the loss of basal and lateral resistance at grounded termini can prolong the dynamic readjustment at the terminus. In contrast to continuous calving, large episodic calving events often occur at floating ice tongues, which can decrease buttressing forces on grounded ice and also increase driving stress and accelerate ice flow (e.g. MacGregor et al., 2012). In the case of floating ice tongues, the response of inland ice to large calving events depends on the amount of lateral resistive stress provided by the tongue prior to calving: the loss of portions of ice tongues that are highly fractured and/or have limited contact with the fjord margins are unlikely to substantially influence inland ice dynamics.

Most previous work at tidewater glaciers in Greenland has concentrated on the central-west and southeast regions, and notably at Jakobshavn Isbræ, Helheim, and Kangerdlugssuaq glaciers (e.g. Howat et al., 2005, 2007; Joughin et al., 2004; Nick et al., 2009). Observations at all three glaciers showed acceleration and surface thinning following terminus retreat. Dynamic changes at Jakobshavn have been linked to the gradual collapse of its floating ice tongue (Amundson et al., 2010; Joughin et al., 2008; Krabill et al., 2004). In northern Greenland, several glaciers have thinned (Rignot et al., 1997), accelerated (Joughin et al., 2010), and retreated, losing large sections of their floating ice tongues between 1990 and 2010 (Box and Decker, 2011; Carr et al., 2017b; Jensen et al., 2016; Moon and Joughin, 2008; Murray et al., 2015). Floating-ice-tongue retreat does not directly contribute to sea level rise. However, with amplified warming and surface melt forecast in northern Greenland (Fettweis et al., 2013; Franco et al., 2011; Mernild et al., 2010), floating ice tongues across the region could soon collapse entirely. As a consequence, northern Greenland could become a more substantial contributor to dynamic mass loss and sea level rise. However, fewer studies have focussed specifically on northern Greenland, with the exception of more detailed work at Petermann Glacier and the Northeast Greenland Ice Stream (NEGIS) (e.g. Khan et al., 2015; Nick et al., 2012). As such, few longterm records of frontal positions exist in the region, and their potential impact on inland ice flow remains unclear.

Here we present changes in frontal position, ice velocity, and surface elevation over the last 68 years (1948 to 2015) in northern Greenland. We couple a multi-decadal annual ter- minus position record between 1948 and 2015 with recently published surface elevation and ice velocity datasets. We then use these datasets to evaluate dynamic responses (i.e. acceleration and thinning) to frontal position change and examine disparities in the context of glaciers with floating or grounded termini. Finally, we assess local topographic setting (i.e. fjord width and depth) as a control on glacier behaviour.

\section{Methods}

\subsection{Study region}

We define northern Greenland as the region of the Greenland Ice Sheet located north of $77^{\circ} \mathrm{N}$ (Fig. 1). This region drains $\sim 40 \%$ of the ice sheet by area (Hill et al., 2017; Rignot and Kanagaratnam, 2006) and includes 18 major marineterminating outlet glaciers, which emanate from 14 major catchments (Fig. 1). Aside from at Petermann Glacier and the NEGIS, little work has focussed on the other glaciers in northern Greenland, where the presence of floating ice tongues could alter the dynamic response of inland ice to calving events. Here, we use the ice-ocean mask from the Operation IceBridge BedMachine v3 product (https://nsidc. org/data/IDBMG4, last access: 1 October 2018) to categorise glaciers in northern Greenland based on either grounded or floating termini (Howat et al., 2014; Morlighem et al., 2017). We also use the grounding line in this dataset to assess the location of past ice tongues. Currently, five glaciers in northern Greenland terminate in floating ice tongues (Fig. 1), which range between 0.5 and $70 \mathrm{~km}$ long (Hill et al., 2017). An additional four glaciers have lost their ice tongues entirely over the last 2 decades (1995-2015). Our study region includes a further nine outlet glaciers, which are grounded at their termini. We note that Humboldt Glacier is classified as grounded as the majority of the $\sim 100 \mathrm{~km}$ long terminus is grounded, despite a small floating ice tongue in the northern section (Carr et al., 2015).

\subsection{Terminus change}

\subsubsection{Data sources}

The terminus positions of 18 study glaciers in northern Greenland (Fig. 1) were manually digitised from a combination of satellite imagery and historical topographic navigational charts between 1948 and 2015 (Table S1). From 1975 to 2015 we used Landsat 1-5 Multispectral Scanner (MSS; 1975-1994), Landsat 7 Thematic Mapper (TM; 2000-2013), and Landsat 8 (2013-2015). These scenes were acquired from the United States Geological Survey (USGS) Earth Explorer website (https://earthexplorer.usgs.gov/, last access: 1 October 2018). To reduce the influence of seasonal changes in terminus position, one scene per year was selected from late summer, and $70 \%$ were within 1 month of 31 August. Several Landsat MSS images required addi- 


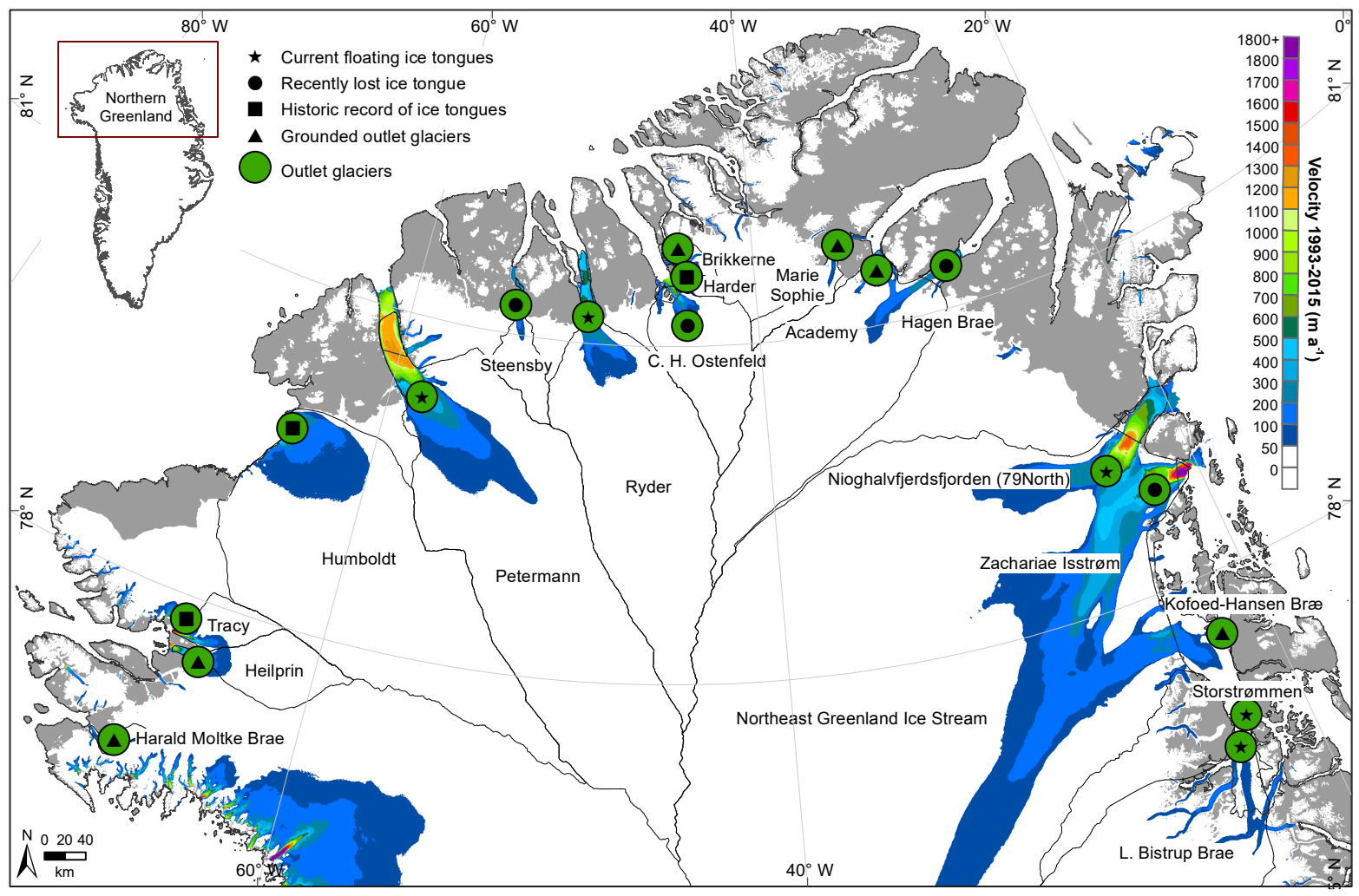

Figure 1. Study region of northern Greenland. Green circles show the location of each of 18 northern Greenland study outlet glaciers. Average glacier velocities $\left(\mathrm{m} \mathrm{a}^{-1}\right)$ are shown between 1993 and 2015 derived from the multi-year mosaic dataset (Joughin et al., 2010). Black outlines show glacier drainage catchments. Symbols represents the state of the glacier terminus. Stars show glaciers which currently have floating ice tongues, circles represent glaciers which lost their ice tongues (during 1995 to 2015), squares denote glaciers which have some previous literature record of a floating ice tongue, and triangles are glaciers which are grounded at their termini and have been throughout the study record.

tional georeferencing and were georeferenced to 2015 Landsat 8 images, as these have the most accurate georeferencing. Early Landsat scenes (1970-1980s) were supplemented with SPOT-1 (Satellite Pour l'Observation de la Terre) imagery from the European Space Agency (ESA) (https://www. intelligence-airbusds.com/, last access: 1 October 2018). These scenes covered 8 of 18 study glaciers in 1986/1987 and were also selected from late August. SPOT-1 scenes were also georeferenced to 2015 Landsat imagery. Additionally, we used aerial photographs ( $2 \mathrm{~m}$ resolution), which were provided orthorectified by Korsgaard et al. (2016). These covered all study glaciers between Humboldt east around to L. Bistrup Bræ in 1978 and Harald Moltke Bræ, Heilprin, and Tracy glaciers in NW Greenland in 1985 (Korsgaard et al., 2016).

To extend the record of glacier terminus positions further back in time, declassified spy images from the Corona satellite were acquired from the USGS Earth Explorer website (Table S1), which covered 5 of 18 glaciers in 1962/1963 and Petermann and Ryder glaciers in 1966. These images were georeferenced to a Landsat 8 scene from 2015, with total root mean square errors (RMSEs) of 105 to $360 \mathrm{~m}$. Frontal position changes smaller than this error value were discounted from the assessment. To further assess the historical terminus positions of the glaciers, we used navigational map charts from the United States Air Force 1:1000 000 Operational Navigation Charts from 1968/1969 (https://legacy.lib. utexas.edu/maps/onc/, last access: 1 October 2018). These were made available through the Perry-Castañeda Library, courtesy of the University of Texas Libraries, Austin. Data from 1948 come from AMS C501 Greenland 1:250 000 Topographic Series Maps distributed by the Polar Geospatial Center (https://www.pgc.umn.edu/data/maps/, last access: 1 October 2018). All maps were georeferenced to 2015 Landsat 8 imagery using a minimum of 10 ground control points (GCPs), which were tied to recognisable stationary features such as on nunataks and fjord walls. RMSEs across all glaciers ranged between 150 and $510 \mathrm{~m}$. 


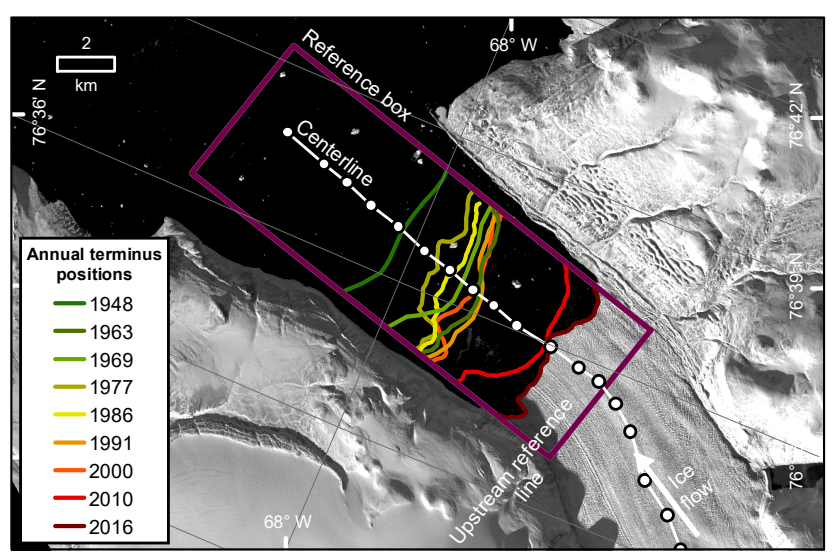

Figure 2. Rectilinear box method used to measure glacier terminus positions. An example at Harald Moltke Bræ, NW Greenland. This includes reference box (pink) and roughly decadal terminus positions (green to red). The glacier centre line profile is shown in white, along with the location of $500 \mathrm{~m}$ sample points (white circles). Background image is Landsat 8 band 8 from the USGS Earth Explorer.

\subsubsection{Front position mapping}

Changes in glacier frontal positions were measured using the commonly adopted box method, which accounts for uneven calving front retreat (e.g. Carr et al., 2013; Howat and Eddy, 2011; Moon and Joughin, 2008). For each glacier, a rectilinear box was drawn parallel to the direction of glacier flow (Fig. 2), extending further inland than the minimum frontal position. Due to Steensby Glacier's sinuous fjord, a curvilinear box was used (see Lea et al., 2014). Glacier frontal positions were digitised in sequential images, and the difference between successive terminus polygons give area changes over time within the box. Dividing these areas by the width of the reference box derives width-averaged relative glacier front positions.

Aside from georeferencing errors outlined in the previous section, the main source of error was attributed to manual digitisation (e.g. Carr et al., 2013; Howat and Eddy, 2012; Moon and Joughin, 2008). We quantified this by repeatedly digitising a $\sim 3 \mathrm{~km}$ section of rock coastline 20 times for each image type or map source. The resultant total mean errors were $3.6 \mathrm{~m}$ for Landsat $8,19 \mathrm{~m}$ for Landsat 7 Enhanced Thematic Mapper (ETM), $17 \mathrm{~m}$ for Landsat MSS, $20 \mathrm{~m}$ for SPOT-1, $16 \mathrm{~m}$ for orthophotographs, $21 \mathrm{~m}$ for Corona, and $27 \mathrm{~m}$ for historical maps. Overall, the mean total error associated with manual digitising was $19 \mathrm{~m}$, which is below the pixel resolution of all imagery sources except the $15 \mathrm{~m}$ panchromatic Landsat band. The presence of sea ice and highly fractured glacier termini made terminus picking at Steensby Glacier, C. H. Ostenfeld Glacier, and glaciers draining the NEGIS more difficult (Bevan et al., 2012; Howat and Eddy, 2012; Murray et al., 2015). Re-digitising all 1999-
2015 Landsat terminus positions yielded additional errors of $\pm 13 \%$ for these glaciers. At these glaciers, similar inaccuracies in identifying the true glacier terminus may have occurred by the authors of the earliest map charts (1948 and 1969), and we therefore consider these to be a broad estimate of the past location of glacier termini rather than exact frontal positions.

\subsubsection{Change point analysis}

"Change point" analysis can be used to objectively identify significant breaks in time series data (Bunce et al., 2018; Carr et al., 2017a). Here we used change point analysis to detect statistically significant breaks in the time series (19482015) of terminus position change for each of our 18 study glaciers in northern Greenland. We then compare the timing and duration of these breaks to determine if distinct patterns of terminus change behaviour exist based on terminus type (grounded or floating). We employ a similar method introduced in more detail by Carr et al. (2017a). To do this, we use the "findchangepts" function in MATLAB software, which employs the methodology of Killick et al. (2012) and Lavielle (2005). Linear regression was used to detect significant breaks in the frontal position time series: a change point was identified where there was a significant change in the mean and regression coefficients (slope and intercept) of the linear regression equation on either side of a data point. In addition, to allow for the fully automatic estimation of the number of change points, we included a minimum threshold penalty value, which we set as the mean terminus position for each glacier. This penalty only allows a change point to occur when the time series deviates significantly from the threshold value. Using these automatically identified change points, we can determine if statistically different changes in the rate of terminus position change exists for study glaciers in northern Greenland according to their terminus type.

\subsection{Ice velocity and surface elevation}

Previously published datasets of annual ice velocity and surface elevation change were compiled to assess dynamic glacier changes in northern Greenland. Velocity and surface elevation change datasets are generally only available from 1990 onwards. The earliest velocity maps from winters 1991/1992 and 1995/1996 were acquired from the European Remote Sensing (ERS) satellites (1 and 2), as part of the ESA Greenland Ice Sheet CCI (Climate Change Initiative) project (Nagler et al., 2016). The earlier one (1991/1992) covers northern Greenland drainage basins from Humboldt and then east to Hagen Bræ, and the later one (1995/1996) covers all 18 study glaciers. Using dataset error maps, we estimated average errors in velocity magnitude across all northern Greenland drainage basins, which were $2.5 \mathrm{~m} \mathrm{a}^{-1}$ for $1991 / 1992$ and $10 \mathrm{~m} \mathrm{a}^{-1}$ for $1995 / 1996$. 
Subsequent velocity datasets were primarily acquired from the NASA Making Earth System Data Records for Use in Research Environments (MEaSUREs) Program (Joughin et al., 2010). These velocity maps were derived from $500 \mathrm{~m}$ resolution interferometric synthetic aperture radar (InSAR) pairs from the RADARSAT-1 satellite in winter 2000/2001 and then annually from winter 2005/2006 to 2009/2010 (Joughin et al., 2010). Using the dataset error values (Joughin et al., 2010), we estimate mean velocity errors across all years and study drainage catchments to be $6.3 \mathrm{~m} \mathrm{a}^{-1}$. For seven study glaciers, additional annual velocity data derived from ERS1, ERS-2, and Envisat satellites were available annually between 1991/1992 and 1997/1998 and between 2003/2004 to 2009/2010 from the ESA Greenland CCI project (Nagler et al., 2016). Winter velocities from these data were calculated from October to April.

For the winters of 2010/2011, 2011/2012, and 2012/2013, glacier velocity maps were also acquired from InSAR (TerraSAR-X image pairs) for 11 of 18 study glaciers (Joughin et al., 2010). Despite higher spatial resolution $(100 \mathrm{~m})$, these maps are limited to the grounding line and extend $27-56 \mathrm{~km}$ inland. Mean error for these data is $23 \mathrm{~m} \mathrm{a}^{-1}$ across all years (Joughin et al., 2010). Winter velocities for 2013/2014 were derived from intensity tracking of RADARSAT-2 satellite data, and from offset tracking of Sentinel-1 radar data for 2014/2015 and 2015/2016, as part of the ESA CCI project (Nagler et al., 2016). The published mean error of these data from a central section of northern Greenland is $7.3 \mathrm{~m} \mathrm{a}^{-1}$ (Nagler et al., 2015). Using the earliest full regional velocity map (1995/1996) and the most recent record (2015/2016), the rate of annual velocity change was calculated over this 20 -year period.

We use surface elevation change data from ERS-1, ERS2, Envisat, and Cryosat-2 radar altimetry for 1992 to 2015, which were made available by the ESA's Greenland Ice Sheet CCI project (Khvorostovsky, 2012; Simonsen and Sørensen, 2017; Sørensen et al., 2015). Data from 1992 to 2011 were acquired from the ERS-1, ERS-2, and Envisat satellites, using a combination of crossover and repeat-track analysis, which were then merged to create a continuous dataset across satellites (Khvorostovsky, 2012). These data are provided in 5-year running means from 1992-1996 to 2007-2011 and at a resolution of $5 \mathrm{~km}$. For the most recent elevation change (2011-2015), we used Crysosat-2 satellite elevation change, which is provided in 2-year means (Simonsen and Sørensen, 2017). These data were generated using the least mean squares method, where grid cells were subtracted from the Greenland Ice Mapping Project (GIMP) digital elevation model (DEM; Howat et al., 2014) and corrected for backscatter and leading edge width (Simonsen and Sørensen, 2017). Calculations were made at a $1 \mathrm{~km}$ grid resolution and resampled to $5 \mathrm{~km}$ to conform with 1992-2011 datasets (Simonsen and Sørensen, 2017). Using error estimates (Simonsen and Sørensen, 2017), we calculated mean errors across all years and across all northern Greenland drainage basins to be $\pm 0.14 \mathrm{~m} \mathrm{a}^{-1}$. Elevation changes from 1992-1996 were compared to elevation changes for 2014-2015 to assess how changes in surface elevation evolved during the study period.

Velocity and surface elevation time series were extracted along each glacier centre line, which were drawn following Lea et al. (2014). To draw these centre lines, we first calculated Euclidean distance between parallel fjord walls that were digitised in 2015 Landsat 8 imagery. The maximum distance line (i.e. centre line) was then traced from the furthest terminus extent back to the inland end of the glacier fjord. Annual average velocities were calculated within $5 \mathrm{~km}$ inland of the grounding line of each glacier, and elevation change rates were averaged across the entire centre line profile due to poorer/coarser data resolution (Fig. 2).

\subsection{Fjord width and basal topography}

To assess the control of fjord geometry on outlet glacier behaviour, we calculate fjord width and depth. Fjord width was measured perpendicular to glacier centre lines following Carr et al. (2014). Points were extracted at $500 \mathrm{~m}$ intervals along each fjord wall and joined by lines that crossed the fjord. The length of these lines is the width between the fjord walls, and changes along each fjord were fitted with a linear regression model to determine if the fjord widens or narrows with distance inland. To determine the fjord bathymetry of each study glacier in northern Greenland, regional basal topography was taken from the Operation IceBridge BedMachine v3 dataset, which is derived from ice thickness and mass conservation (Morlighem et al., 2017). Basal topography was sampled at $500 \mathrm{~m}$ points along glacier centre lines. Using the error map from BedMachine v3 (Fig. S1), we calculated errors along the grounded and non-grounded portions of each glacier centre line profile (Table S2). Mean grounded bed topography errors at 14 of 18 study glaciers range between 25 and $87 \mathrm{~m}$. These glaciers are well constrained by the mass conservation method, which works best for fast-flowing areas near the glacier terminus (Morlighem et al., 2014, 2017). The remaining four glaciers (Storstrømmen, L. Bistrup Bræ, Kofoed-Hansen Bræ, and Brikkerne Glacier) have higher errors (from 112 to $215 \mathrm{~m}$ ), owing to poor data coverage and kriging interpolation (Morlighem et al., 2017). Mean errors in bathymetry data are greater at all glaciers, averaging $156 \mathrm{~m}$ and ranging from 15 to $283 \mathrm{~m}$. To assess bed slope direction, we fit each glacier profile from the grounding line to $20 \mathrm{~km}$ inland with a linear regression model. These sections of each bed profile and model fit are presented in Fig. S2, while entire bed profiles and landward/seaward direction are presented in the results. Errors in basal topography do not significantly affect our assessment of bed slope direction, and we only use topography along the grounded portion of the glacier where errors are lowest. We treat basal profiles in the far east of the study region with caution due to their higher errors. Finally, to estimate drainage catchment areas and the percentage of each catchment below present sea level for each study 


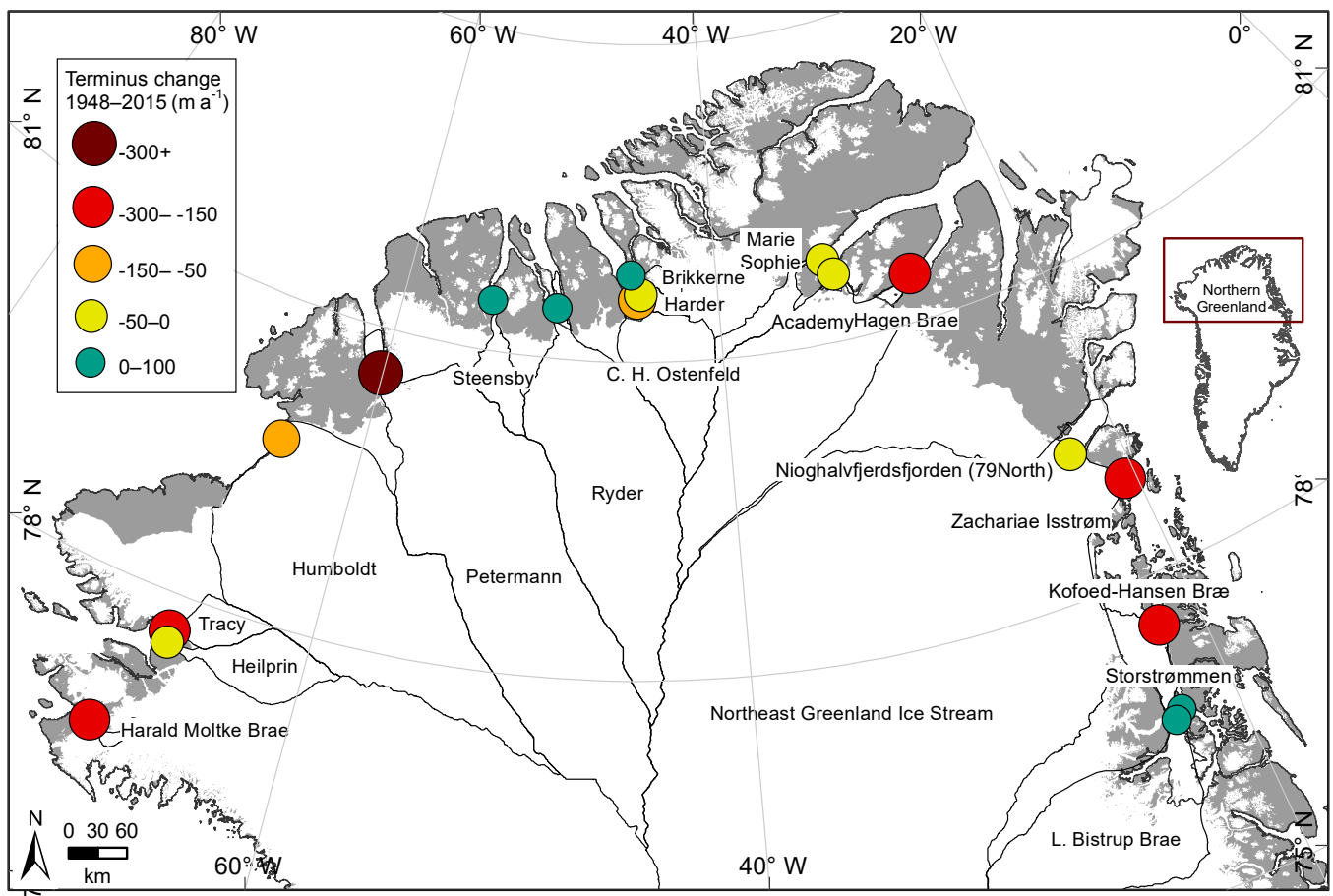

Figure 3. Overall mean rate of terminus change $\left(\mathrm{m} \mathrm{a}^{-1}\right)$ at 18 outlet glaciers in northern Greenland from 1948 to 2015 . Green circles represent glaciers which have undergone overall advance during the record, while yellow to red circles represent increasing retreat rates from 0 to larger than $-300 \mathrm{~m} \mathrm{a}^{-1}$.

Table 1. Summary data for 18 northern Greenland outlet glaciers, ordered according to terminus type and by frontal position rate (from high retreat to high advance). Annual rates of terminus change are given for the entire record (1948-2015). Average velocity change along each glacier centre line from winter $1995 / 1996$ to 2015/2016. Average surface elevation change rates along each glacier centre line were differenced from the earliest record (1992-1996) and the most recent (2014/2015).

\begin{tabular}{|c|c|c|c|c|c|}
\hline & & $\begin{array}{l}\text { Northern Greenland } \\
\text { outlet glaciers }\end{array}$ & $\begin{array}{r}\text { Terminus change } \\
(1948-2015) \\
\left(\mathrm{m} \mathrm{a}^{-1}\right)\end{array}$ & $\begin{array}{r}\text { Velocity change } \\
(1995 / 1996- \\
2015 / 2016)\left(\mathrm{m} \mathrm{a}^{-1}\right)\end{array}$ & $\begin{array}{l}\text { Difference in surface elevation } \\
\text { change rates }(1992-1996 \\
\text { and } 2014-2015)\left(\mathrm{m} \mathrm{a}^{-1}\right)\end{array}$ \\
\hline \multirow{9}{*}{$\begin{array}{l}\ddot{-} \\
\stackrel{0}{0} \\
\stackrel{0}{0} \\
\stackrel{0}{0}\end{array}$} & \multirow{9}{*}{ 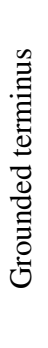 } & Tracy & -173 & 36.8 & -0.11 \\
\hline & & Kofoed-Hansen Bræ & -169 & -0.06 & 0.12 \\
\hline & & Harald Moltke Bræ & -156 & 22.6 & \\
\hline & & Humboldt & -111 & 0.32 & -0.51 \\
\hline & & Heilprin & -45 & 7.16 & -0.15 \\
\hline & & Academy & -31 & -4.87 & -0.97 \\
\hline & & Harder & -25 & 0.58 & -0.89 \\
\hline & & Marie-Sophie & -15 & 1.03 & -0.43 \\
\hline & & Brikkerne & 82 & -2.56 & \\
\hline \multirow{9}{*}{ 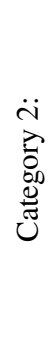 } & \multirow{9}{*}{ 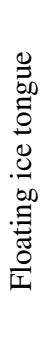 } & Petermann & -311 & 3.78 & -1.34 \\
\hline & & Zachariae Isstrøm & -282 & 20.3 & -2.98 \\
\hline & & Hagen Bræ & -162 & 6.45 & -0.83 \\
\hline & & C. H. Ostenfeld & -58 & 2.96 & -1.26 \\
\hline & & Nioghalvfjerdsfjorden & -28 & 1.62 & -1.99 \\
\hline & & Steensby & 2 & 2.59 & -0.33 \\
\hline & & L. Bistrup Bræ & 39 & -3.89 & 0.57 \\
\hline & & Storstrømmen & 41 & -1.11 & -0.18 \\
\hline & & Ryder & 43 & -0.08 & 0.47 \\
\hline
\end{tabular}


glacier, surface drainage catchments (Table 3) were delineated using the GIMP surface DEM (Howat et al., 2014) and topographic analysis functions within TopoToolbox in MATLAB (Schwanghart and Kuhn, 2010). We calculated each drainage area using catchments constrained by gradients in the surface DEM.

\section{Results}

\subsection{Changes in glacier frontal position (1948-2015)}

Across northern Greenland, 13 of the 18 study glaciers underwent net retreat between 1948 and 2015, while the remaining five advanced (Fig. 3). However, long-term frontal retreat rates (1948-2015) varied between glaciers across northern Greenland (Table 1) and ranged from $-15 \mathrm{ma}^{-1}$ at Marie-Sophie Glacier to 20 times greater at Petermann Glacier $\left(-311 \mathrm{~m} \mathrm{a}^{-1}\right)$. At outlet glaciers in northern Greenland, we expect terminus changes and dynamic response to be different dependent on terminus type (i.e. floating or grounded). Nine outlet glaciers were grounded at their terminus throughout the study period, while at the end of the study period another nine still had ice tongues or had lost them during the last 2 decades (1996-2015, Fig. 1, Table 1). Our statistical change point analysis compared the duration and magnitude of frontal position changes at all study glaciers: this confirms that, in general, there are two different types of frontal position behaviour and dynamic response to calving based on terminus type (grounded or floating).

In addition to the long-term record of frontal position change (1948-2015), we further assess the variability of retreat rates across northern Greenland, by presenting mean retreat rates across five decadal time periods (1976-1985, 1986-1995, 1996-2005, 2006-2015) in Fig. 4a-e, except for the earliest epoch (1948-1975), which spans 27 years due to image availability. We also present mean decadal frontal position change based on terminus type in Table 2. During the first epoch (1948-1975) small advances and retreats took place across the region $\left(<500 \mathrm{~m} \mathrm{a}^{-1}\right.$ magnitude). This was followed by a decade (1976-1985) dominated by glacier advance, in particular at glaciers with floating ice tongues (Table 2), which had high retreat rates for the entire study period (e.g. Hagen Bræ, Zachariae Isstrøm, Petermann; Table 1). In the subsequent epoch (1986-1995), a mixture of advance and retreat occurred, and the range of frontal position changes was great, from $-780 \mathrm{~m} \mathrm{a}^{-1}$ retreat at C. H. Ostenfeld Glacier to $750 \mathrm{~m} \mathrm{a}^{-1}$ advance at Storstrømmen (Fig. 4c). During the last 2 decades of the study period (1996-2015), retreat rates were substantially higher than in the previous three epochs. However, variability in the magnitude of frontal position change over this period appears to be particularly related to terminus type (grounded or floating). Decadal mean retreat rates at glaciers with ice tongues $(-745$ to $-835 \mathrm{~m} \mathrm{a}^{-1}$ ) were substantially higher than at grounded out- let glaciers ( -99 to $165 \mathrm{~m} \mathrm{a}^{-1}$, Table 2). Based on the differences in terminus behaviour observed over the long-term and decadal time series based on terminus type (grounded or floating), we now treat these as separate categories for the remainder of the results, during which we describe short-term trends derived from our change point analysis (Fig. 5).

\subsubsection{Grounded-terminus outlet glaciers}

Calving-induced retreat of grounded marine-terminating outlet glaciers contributes to dynamic mass loss and directly to sea level rise. At grounded outlet glaciers in northern Greenland (nine of our study glaciers, Fig. 5), retreat rates increased substantially during the last 2 decades (19962015) of the study period. At the beginning of our record, grounded outlet glaciers went through an initial period of minimal frontal position change averaging $-26 \mathrm{~m} \mathrm{a}^{-1}$ and ranging from $24 \mathrm{~m} \mathrm{a}^{-1}$ advance at Kofoed-Hansen Bræ to $-105 \mathrm{~m} \mathrm{a}^{-1}$ retreat at Tracy Glacier (Fig. 5). Frontal position change then switched to a period of higher-magnitude retreat at eight glaciers (excluding Brikkerne), which lasted for an average of 26 years. During this period, frontal position change averaged $-150 \mathrm{ma}^{-1}$, and net retreats ranged from -0.6 to $8 \mathrm{~km}$. The greatest total terminus changes took place at Tracy Glacier (8 km retreat: 1981-2015), Harald Moltke Bræ (5 km retreat: 1988-2015), and Kofoed-Hansen Bræ (4.6 km: 1973-2015; Fig. 6a-c). The timing of this switch from minimal change to steady retreat was not uniform, but most glaciers began steadily retreating from the 1990s to 2000s and continued at the same rate thereafter (Fig. 5). The exception to this pattern of behaviour is Brikkerne Glacier, which instead advanced by $9 \mathrm{~km}$ between 1968 and 1978 before returning to minimal terminus change (Fig. 6i).

\subsubsection{Glaciers with floating ice tongues}

The retreat of floating glacier termini can reduce the resistive stresses at the terminus and increase the dynamic glacier response to calving. Rapid retreat in the form of large episodic calving events removed substantial floating ice sections (11.6-26 km net retreat; Fig. 7) from several northern Greenland outlet glaciers (Zachariae Isstrøm, Petermann Glacier and Steensby Glacier, C. H. Ostenfeld Glacier, and Hagen Bræ) between 1995 and 2015. However, frontal position changes at some glaciers with floating ice tongues were instead cyclic. At the beginning of the study period, six of the nine study glaciers with floating ice tongues showed minimal terminus change/advance $\left(93 \mathrm{~m} \mathrm{a}^{-1}\right)$, followed by short-lived rapid retreat, lasting less than 6 years on average (Fig. 5). During the phases of rapid retreat, rates ranged between $-700 \mathrm{~m} \mathrm{a}^{-1}$ at Nioghalvfjerdsfjorden and $-8997 \mathrm{~m} \mathrm{a}^{-1}$ at Petermann Glacier (Fig. 5), and were on average 40 times greater $\left(-4536 \mathrm{~m} \mathrm{a}^{-1}\right)$ than during the steady retreat phases at glaciers grounded at their terminus $\left(-150 \mathrm{~m} \mathrm{a}^{-1}\right)$. During this period, large calving events led to complete ice tongue 


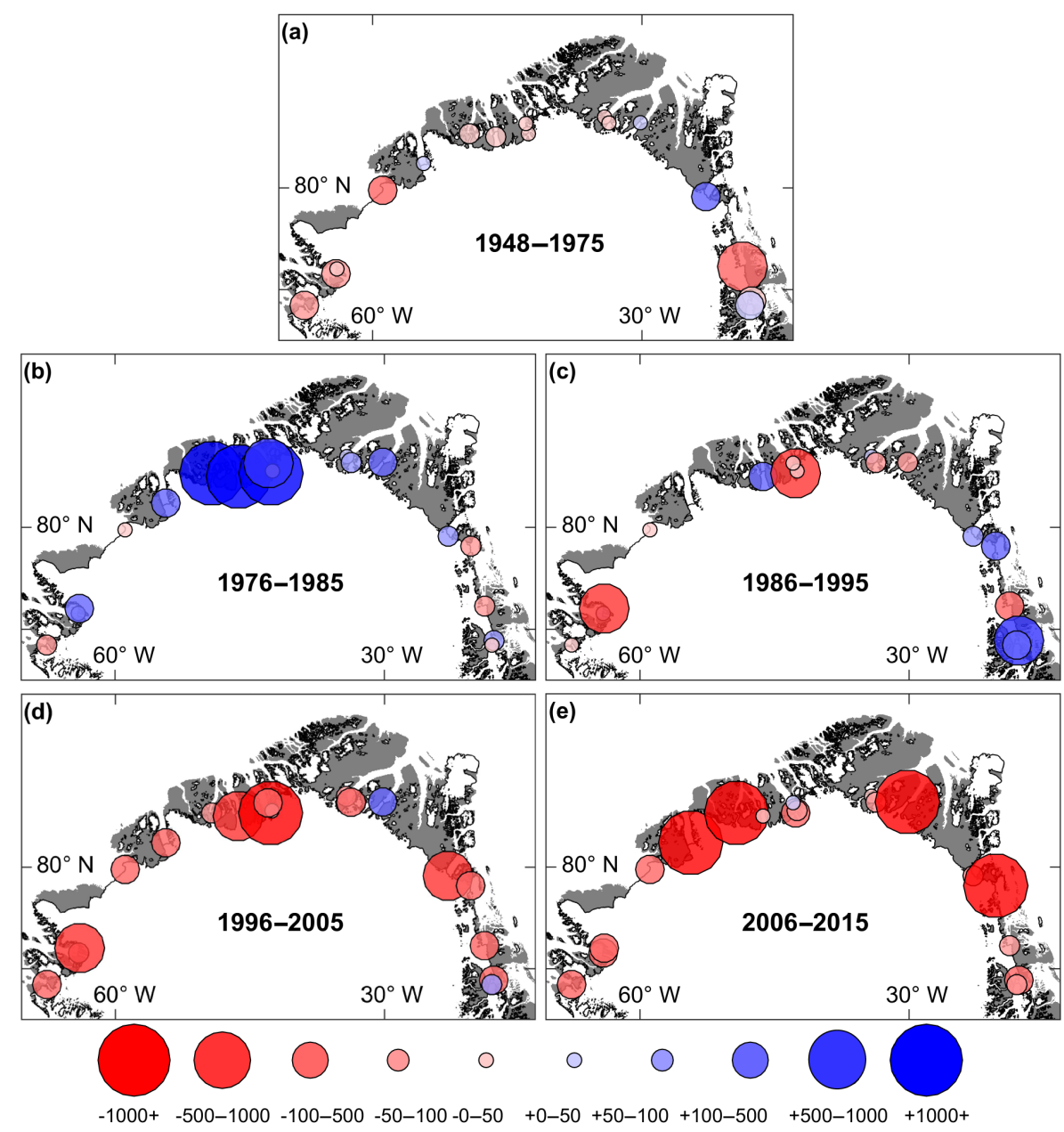

Figure 4. Mean decadal rates of terminus change across northern Greenland. These are shown for five epochs between 1948 and 2015. Increasing red circles represent glacier retreat rates between 0 and exceeding $-1000 \mathrm{~m} \mathrm{a}^{-1}$. Increasing blue circles represent advance rates between 0 and exceeding $1000 \mathrm{ma}^{-1}$.

Table 2. Mean decadal frontal position change for all study outlet glaciers in northern Greenland, and split based on our two glacier categories of terminus type: grounded terminus or terminating in a floating ice tongue.

\begin{tabular}{lrrrrr}
\hline Mean terminus change $\left(\mathrm{m} \mathrm{a}^{-1}\right)$ & $1948-1975$ & $1976-1985$ & $1986-1995$ & $1996-2005$ & 2006-2015 \\
\hline All $(n=18)$ & -63.65 & 503.36 & -7.83 & -454.99 & -467.06 \\
Grounded terminus $(n=9)$ & -167.35 & 93.87 & -112.07 & -164.50 & -99.23 \\
Floating terminus $(n=9)$ & 40.05 & 912.84 & 126.19 & -745.49 & -834.88 \\
\hline
\end{tabular}

loss at Zachariae Isstrøm by $2011 / 2012$ and at C. H. Ostenfeld Glacier, Steensby Glacier, and Hagen Bræ by 2016 (Fig. 7). Rapid retreat was often followed by another period of relative minimal terminus change $\left(-437 \mathrm{~m} \mathrm{a}^{-1}\right)$ compared to order-of-magnitude earlier retreat (e.g. Petermann Glacier and Hagen Bræ, Fig. 5). Similar to glaciers with grounded termini, the timing of the switch to rapid retreat was not synchronous, but mainly occurred after 1990 (Fig. 5). At most glaciers, the duration of rapid retreat was short-lived
$(<5$ years) in comparison to the duration of steady retreat $(>13$ years) at grounded glaciers.

Several glaciers with floating ice tongues (Storstrømmen, L. Bistrup Bræ, and Ryder) have instead shown cyclic periods of advance and retreat between 1948 and 2015 (Fig. 7gi). Periods of terminus advance at these glaciers averaged $\sim 420 \mathrm{~m} \mathrm{a}^{-1}$ and lasted for an average of 18 years (Fig. 5). Adjacent glaciers Storstrømmen and L. Bistrup Bræ advanced during a similar period (from 1973 to 1990) for 13-17 years. After this, both glaciers underwent relatively 


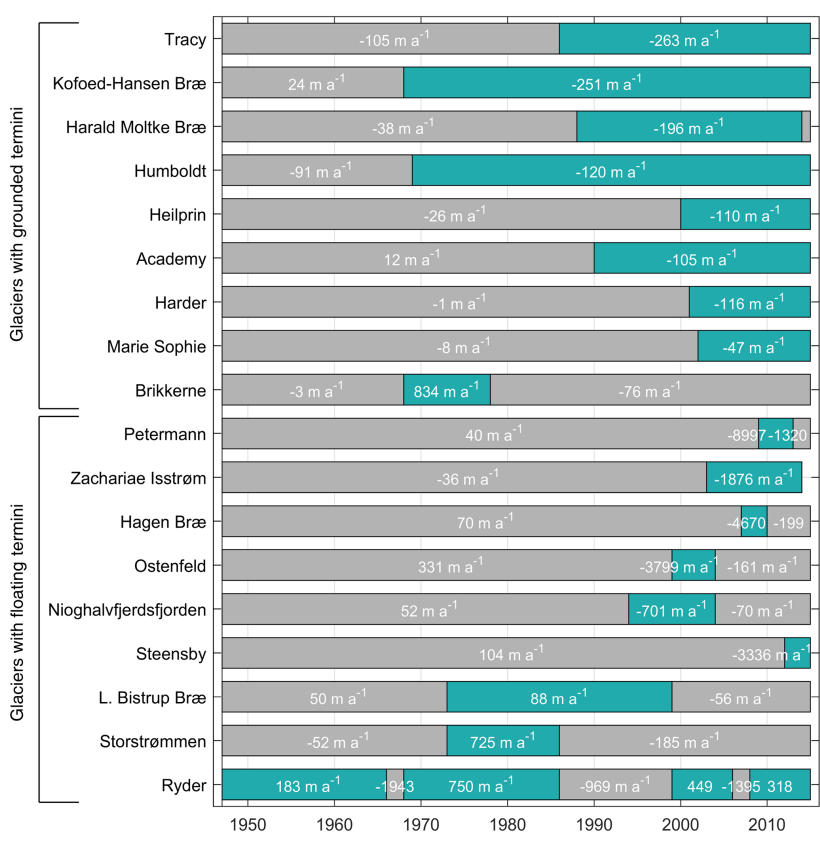

Figure 5. Retreat rates during identified change point time periods for each pre-defined category of glacier based on either grounded or floating termini. Glaciers are then ordered based on their overall (1948-2015; Table 1) frontal position change rates within each of these categories. Grey bars show their periods of minimal/variable terminus change (in some cases advance), and turquoise bars show the period of higher-magnitude frontal position change.

limited terminus change from 2000 onwards (Fig. 5). Despite synchronous advance, their advance rates differed by almost an order of magnitude $\left(89 \mathrm{~m} \mathrm{a}^{-1}\right.$ at L. Bistrup Bræ and $725 \mathrm{~m} \mathrm{a}^{-1}$ at Storstrømmen, Fig. 5). At Ryder Glacier, there were four main cycles of glacier advance and retreat during the record. These took place during 1948-1996, 1968-1986, 1999-2006, and 2008-2015, and advance rates ranged from 183 to $750 \mathrm{~m} \mathrm{a}^{-1}$ (Fig. 5). Periods of advance (7-48 years) were separated by shorter periods (2-13 years) of highermagnitude retreat (ranging from -960 to $-1950 \mathrm{~m} \mathrm{a}^{-1}$ ) (Fig. 5).

\subsection{Ice velocity change}

\subsubsection{Grounded-terminus outlet glaciers}

Overall, most grounded outlet glaciers in northern Greenland accelerated along their centre line profiles (ranging from 0.32 to $37 \mathrm{~m} \mathrm{a}^{-1}$ ) from 1996 to 2016 (Table 1). Acceleration at these glaciers was also greatest (averaging 27\%) during periods of steady retreat (Fig. 5). This was particularly the case in northwest Greenland at Heilprin, Tracy, and Harald Moltke Brae. At Heilprin Glacier this resulted in a $49 \%$ increase (from 458 to $681 \mathrm{~m} \mathrm{a}^{-1}$ ) in groundingline velocity from 2001 to 2016 (Fig. 6e), during which the glacier retreated at $-110 \mathrm{ma}^{-1}$ (Fig. 5). Substantially greater acceleration ( $89 \%)$ took place at Tracy Glacier from 1996 to 2016 (Fig. 6a), which was associated with highermagnitude retreat rates $\left(-263 \mathrm{~m} \mathrm{a}^{-1} ;\right.$ Fig. 5$)$. Harald Moltke Bræ also accelerated between 1990 and $2016\left(22 \mathrm{~m} \mathrm{a}^{-1}\right.$, Table 1), and retreated at $-196 \mathrm{~m} \mathrm{a}^{-1}$ (Fig. 5). However, it underwent two very large velocity increases $\left(>1000 \mathrm{~m} \mathrm{a}^{-1}\right)$ between 2001 and 2006 and again during winter 2013/2014, both of which coincided with short-lived glacier advance $(0.5-0.8 \mathrm{~km}$; Fig. $6 \mathrm{c})$. More slowly flowing grounded outlet glaciers in the region $\left(<400 \mathrm{~m} \mathrm{a}^{-1}\right.$ : Humboldt, Harder, and Marie-Sophie glaciers) also accelerated by $27-108 \%$ during steady retreat (Fig. 6). Alternatively, some groundedterminus outlet glaciers did not show substantial acceleration following retreat: Kofoed-Hansen Bræ and Academy Glacier had sustained periods of steady retreat but showed no net trend in velocity and high variability (Fig. 6b, f), which did not coincide with periods of increased retreat rates (Fig. 5). Brikkerne Glacier decelerated from 1996 to 2016, while the terminus position changed little (Fig. 6i).

\subsubsection{Glaciers with floating ice tongues}

Despite major retreat episodes and ice tongue disintegration, most glaciers in northern Greenland that terminate in floating ice tongues (except Zachariae Isstrøm) showed minimal net velocity change between 1996 and 2016 (Table 1). In contrast to grounded outlet glaciers, the velocity response to retreat was also more variable between individual glaciers. However, we identify two main patterns in velocity change following periods of rapid retreat: (1) shortlived, minimal glacier acceleration, followed by some deceleration, and (2) continuous acceleration following initial terminus retreat. The first pattern of velocity change encompasses seven of nine glaciers with floating ice tongues, the clearest examples of which are at C. H. Ostenfeld Glacier, Hagen Bræ, Petermann Glacier, and Steensby Glacier. In all cases, rapid ice tongue retreat was followed by shortlived ( $<3$-year) low-magnitude $(<8 \%$ acceleration, but $\sim$ $25 \%$ at Steensby) grounding-line acceleration. After retreat ceased, ice flow decelerated, ranging from $2 \%$ at Petermann to $28 \%$ at Hagen Bræ. In addition, prior to rapid retreat some glaciers advanced. In the year preceding rapid retreat (20052006), Hagen Brae showed higher-magnitude acceleration ( $\sim 52 \%$ ) alongside some glacier advance. This was also the case at Ryder Glacier, which showed cyclic behaviour of grounding-line acceleration $\left(\sim 8 \%: 4.7-5.5 \mathrm{~m} \mathrm{a}^{-1}\right)$ during both 7-year periods of terminus advance, followed by deceleration $(11 \%)$ during high-magnitude retreat $(\sim 2$ years) in between periods of advance. Storstrømmen and L. Bistrup Bræ also show evidence of some acceleration immediately following retreat, later followed by deceleration (Fig. 7h, i) from 2010 to 2016. However, in contrast to most glaciers which flow fastest at their terminus, velocities at both glaciers are fastest inland and decrease with distance towards the terminus (Fig. 8). Grounding-line terminus velocities acceler- 

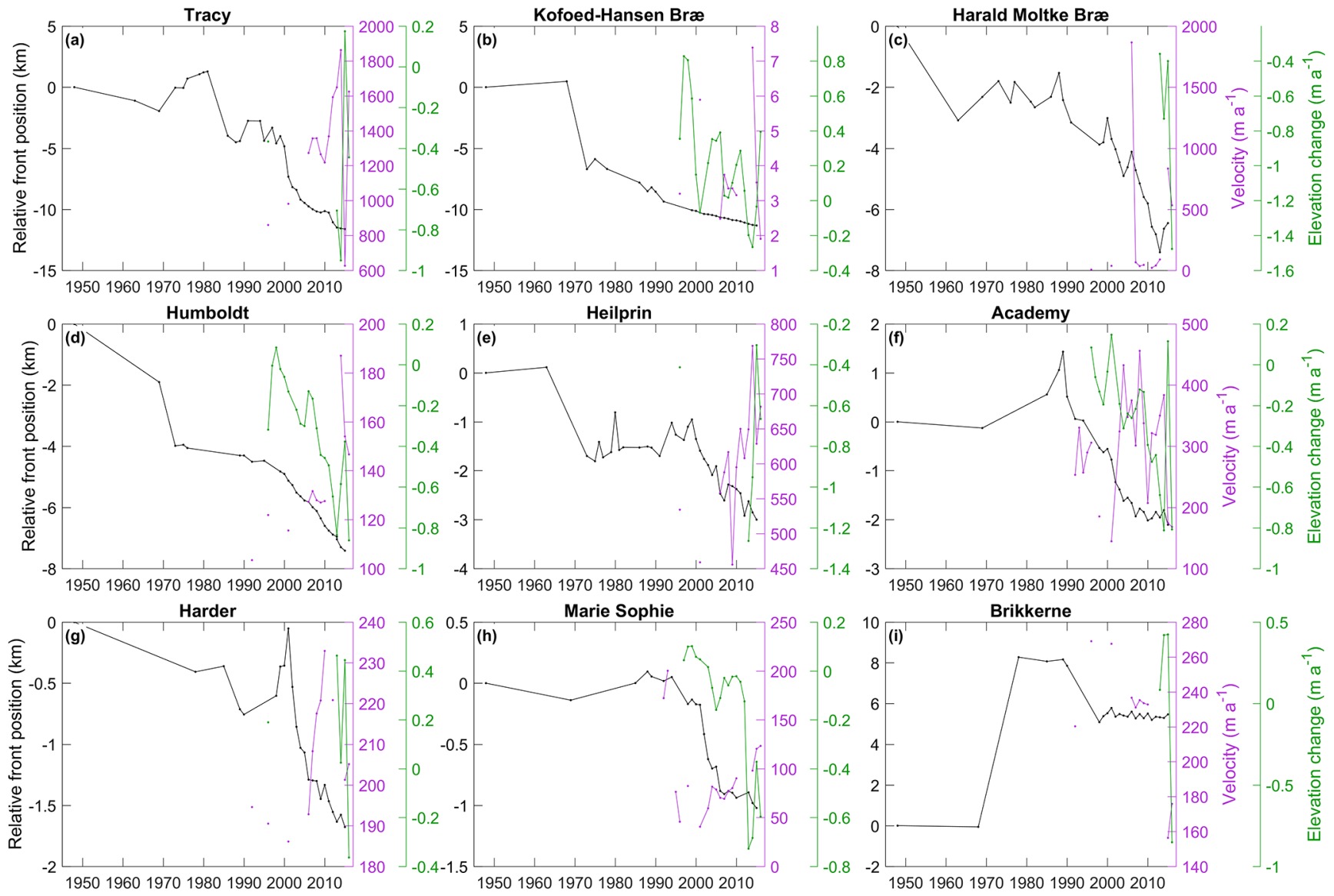

Figure 6. Front position and velocity and elevation change at nine outlet glaciers grounded at their terminus in northern Greenland. Left axes show relative front position (black line) between 1948 and 2015 relative to their initial position in 1948; right axes show grounding-line velocities (purple) between 1996 and 2015. Surface elevation changes averaged across the glacier centre line profile (green) for 1996 to 2015.

ated by $350 \%$ and $150 \%$ at Storstrømmen and L. Bistrup Bræ throughout the record (1996-2016; Fig. 7); velocities $\sim 20-40 \mathrm{~km}$ inland decelerated by $10-15 \mathrm{~m} \mathrm{a}^{-1}$ (> 54\%).

The second pattern of velocity change occurred at both glaciers draining the NEGIS where ice tongue retreat was followed by gradual glacier acceleration in the subsequent decade (2006-2016: $43 \%$ at Zachariae Isstrøm and 10\% at Nioghalvfjerdsfjorden). This prolonged glacier acceleration following retreat is more similar to patterns observed on grounded termini, rather than the other floating tongues. Further, the removal of the entire ice tongue at Zachariae Isstrøm in 2011/2012 was followed by glacier acceleration (125 $\mathrm{m} \mathrm{a}^{-2}: 2012-2016$; Fig. $7 \mathrm{~g}$ ), whereas other glaciers (e.g. C. H. Ostenfeld Glacier and Hagen Bræ) underwent a similar collapse, but changes in velocities were limited. Despite this behaviour in the northeast of the study region, the majority of glaciers in northern Greenland showed negligible acceleration in response to retreat and/or collapse of their floating ice tongues.

\subsection{Surface elevation change}

\subsubsection{Grounded-terminus outlet glaciers}

Alongside continuous retreat and acceleration at outlet glaciers with grounded termini, thinning rates increased between 1992-1996 and 2014-2015 (Table 1). In most cases, surface lowering was synchronous with the start of their steady retreat (Fig. 6). Examples of this were at MarieSophie and Academy glaciers, where small increased thinning or reduced thickening rates (1999-2000; Fig. 6f, h) were followed by high retreat rates in the following years at both Marie-Sophie Glacier $\left(-130 \mathrm{ma}^{-1}\right.$ : 2001-2004) and Academy Glacier $\left(-205 \mathrm{~m} \mathrm{a}^{-1}: 2001-2003\right)$. Periods of greater retreat (2001-2003/2004) were followed by dramatically increased thinning rates at both glaciers to $-0.3 \mathrm{~m} \mathrm{a}^{-1}$ (Academy) and $-0.16 \mathrm{ma}^{-1}$ (Marie-Sophie; Fig. 6f, h). Thinning rates similarly increased strongly from -0.19 to $-0.78 \mathrm{~m} \mathrm{a}^{-1}$ at Humboldt Glacier from 1996-2005 to 20052012 , which coincided with increased retreat rates $(-98$ to $-160 \mathrm{ma}^{-1}$; Fig. 6d). Limited data prevent us from com- 

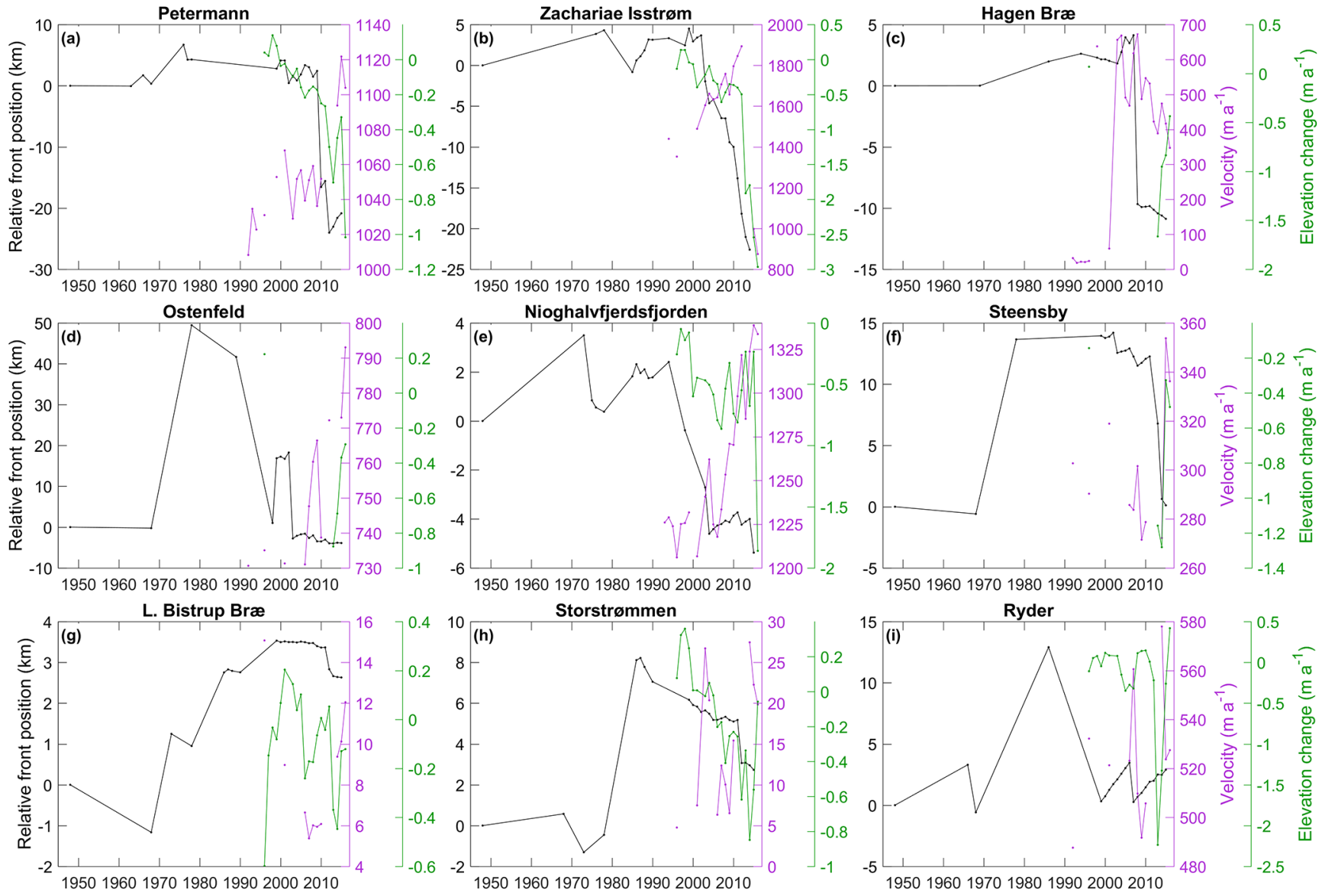

Figure 7. Front position and velocity and elevation change at nine outlet glaciers which terminate in floating ice tongues in northern Greenland. Left axes show front position (black line) between 1948 and 2015 relative to their initial position in 1948; right axes show grounding-line velocities (purple) on between 1996 and 2015. Surface elevation changes averaged across the glacier centre line profile (green) for 1996 to 2015 .

menting in depth on elevation changes at glaciers in NW Greenland. However, the few years of data available at Harald Moltke Bræ show increased thinning between 2012 and 2015, coincident with retreat (Fig. 6c). Within this record lies an anomalous year of reduced thinning rates (2013-2014), which were coincident with an order-of-magnitude increase in velocity $\left(\sim 1000 \mathrm{~m} \mathrm{a}^{-1}\right)$ and $0.8 \mathrm{~km}$ terminus advance.

\subsubsection{Glaciers with floating ice tongues}

In general, glaciers with floating ice tongues had higher thinning rates than grounded termini from 1992-1996 to 20142015 (Table 1), and were characterised by short-lived increases in thinning rates following ice tongue retreat. In several cases (e.g. Petermann, Hagen Bræ, and Zachariae Isstrøm), slight thickening occurred before ice tongue retreat/collapse, followed by a switch to thinning immediately before large calving events (Fig. 7). For example, Petermann Glacier switched from negligible thickening in 2008 $\left(0.03 \mathrm{~m} \mathrm{a}^{-1}\right)$ to thinning $\left(-0.22 \mathrm{~m} \mathrm{a}^{-1}\right)$ in 2009 , before the removal of $27 \mathrm{~km}$ of floating ice in the following 3 years (2010-2013; Fig. 7a). At Zachariae Isstrøm a switch to thinning was synchronous with the onset of rapid retreat in 2003 (Fig. 7b), although thinning rates were greater once the entire ice tongue was lost (2011-2012). During or immediately after floating-ice-tongue retreat, thinning rates increased from minimal change $\left(<-0.2 \mathrm{~m} \mathrm{a}^{-1}\right.$ thinning) to $-0.8 \mathrm{~m} \mathrm{a}^{-1}$ at Petermann Glacier (2010-2013), $-1.7 \mathrm{~m} \mathrm{a}^{-1}$ at Hagen Bræ (2007/2011-2012/2013), and $-2 \mathrm{~m} \mathrm{a}^{-1}$ at Zachariae Isstrøm (2011/2012-2012/2013; Fig. 7). This increased thinning was also coincident with acceleration during the years following ice tongue removal (Fig. 7). Other glaciers showed more gradual and smaller increases in thinning rates (Fig. 7). For example, at C. H. Ostenfeld Glacier the removal of $21 \mathrm{~km}$ of floating ice between 2002 and 2003 was followed by a steady and low-magnitude increased thinning rates at a rate of $-0.15 \mathrm{~m} \mathrm{a}^{-1}$ from 2006 to 2014 (Fig. 7d). In this case, velocity increases alongside increased thinning rates were also gradual, but minimal in comparison to other glaciers. Ryder Glacier also showed increased thinning rates prior to retreat 


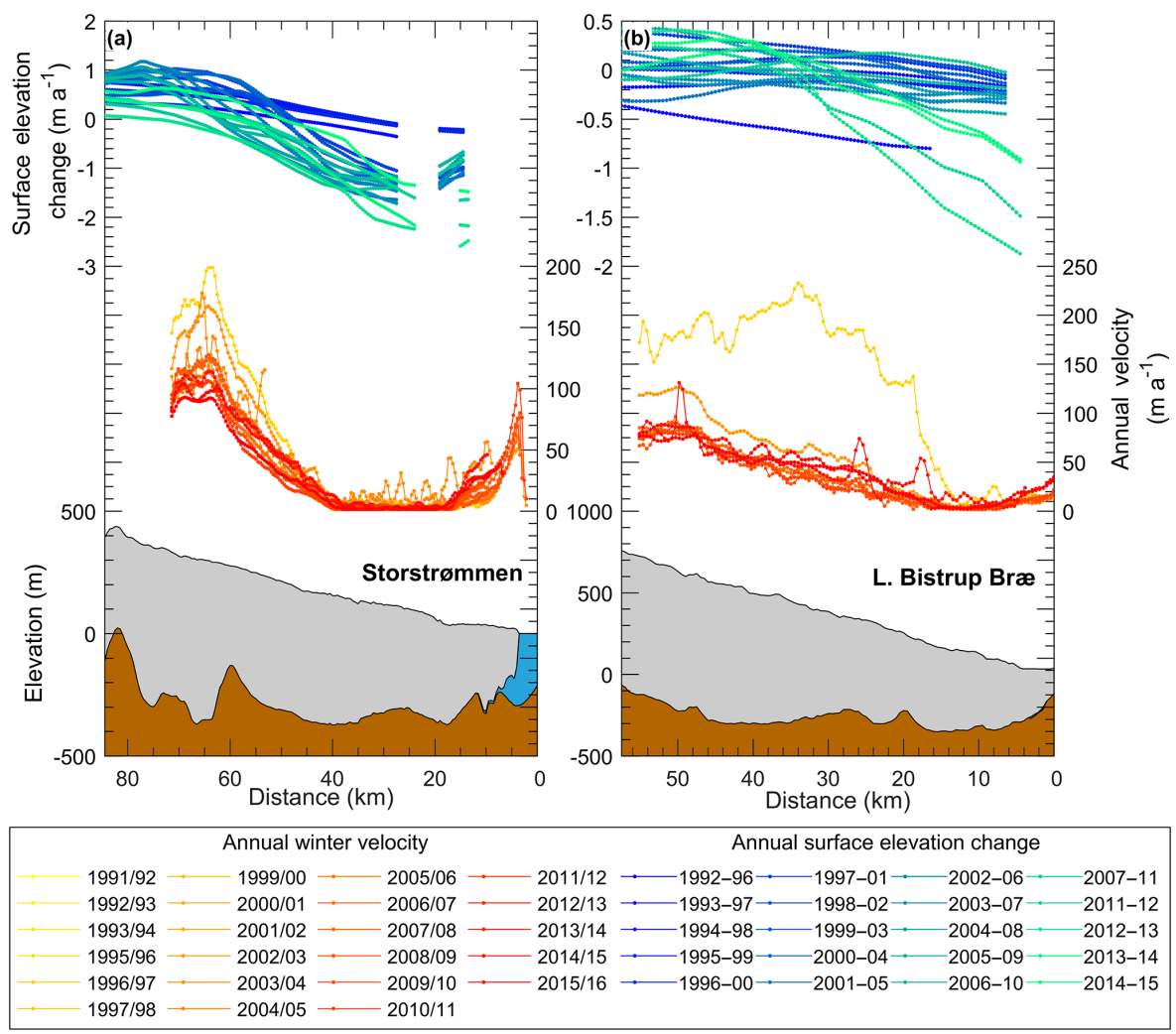

Figure 8. Annual surface elevation change, annual velocity, and surface/bed topography for two outlet glaciers in northeast Greenland: Storstrømmen (a) and L. Bistrup Bræ (b). Blue to green coloured lines represent annual surface elevation through time (1992-1996 to 2014-2015), and yellow to red lines represent annual winter velocity from 1991/1992 to 2015/2016.

(2005-2006), but they were followed by a rapid switch to thickening as ice flow accelerated and the calving front advanced (Fig. 7i).

Two glaciers with floating ice tongues in northeast Greenland showed a different pattern of elevation change to the rest of the region: Storstrømmen and L. Bistrup Bræ thinned at the glacier terminus and thickened inland from 1996 to 2015 (Fig. 8). Periods of glacier advance ( 1970s-1980s) at both Storstrømmen and L. Bistrup Bræ preceded the earliest record of elevation change; following this, their terminus positions underwent minimal change (Fig. 5). Between 1996 and 2015, inland elevation change was minimal (Fig. 8), whereas greater thinning took place at the terminus. Large retreat events of $2.1 \mathrm{~km}$ at Storstrømmen and $0.7 \mathrm{~km}$ at L. Bistrup Bræ between 2011 and 2013 coincided with increased terminus thinning rates of $-0.8 \mathrm{~m} \mathrm{a}^{-1}$ at Storstrømmen (2011-2012) and $-1.76 \mathrm{~m} \mathrm{a}^{-1}$ at L. Bistrup Bræ (20112013; Fig. 8). These spatial patterns of elevation change were synchronous with velocity variations: deceleration and thickening occurred inland, while acceleration, thinning, and retreat were synchronous at the terminus (Fig. 8).

\subsection{Topographic factors}

\subsubsection{Grounded-terminus outlet glaciers}

Distinct variability in glacier geometry exists between individual outlet glaciers in northern Greenland. At many outlet glaciers with grounded termini (Harald Moltke Brae, Heilprin, Tracy, and Humboldt), deep inland-sloping beds are associated with higher retreat rates (averaging $-121 \mathrm{~m} \mathrm{a}^{-1}$ ), and greater increases in velocity (Table 1 ). These glaciers rest between -33 and $-370 \mathrm{~m}$ below sea level (Fig. 9) and appear to have been retreating down steep bed slopes (Fig. S2) away from topographic ridges at the end of their fjords (Fig. 9). However, variability in fjord width (widening/narrowing) does not appear to be a main determinant of higher retreat rates (Table 3). Additionally, some grounded outlets (Harder, Academy, and Marie-Sophie) have shallower seaward-sloping topography which correlated with lowermagnitude retreat rates $\left(-24 \mathrm{~m} \mathrm{a}^{-1}\right.$, Table 1$)$.

\subsubsection{Glaciers with floating ice tongues}

Basal topography beneath floating ice tongues does not impact their dynamic response to retreat. Instead, we examine bed topography inland of the grounding line, which may 


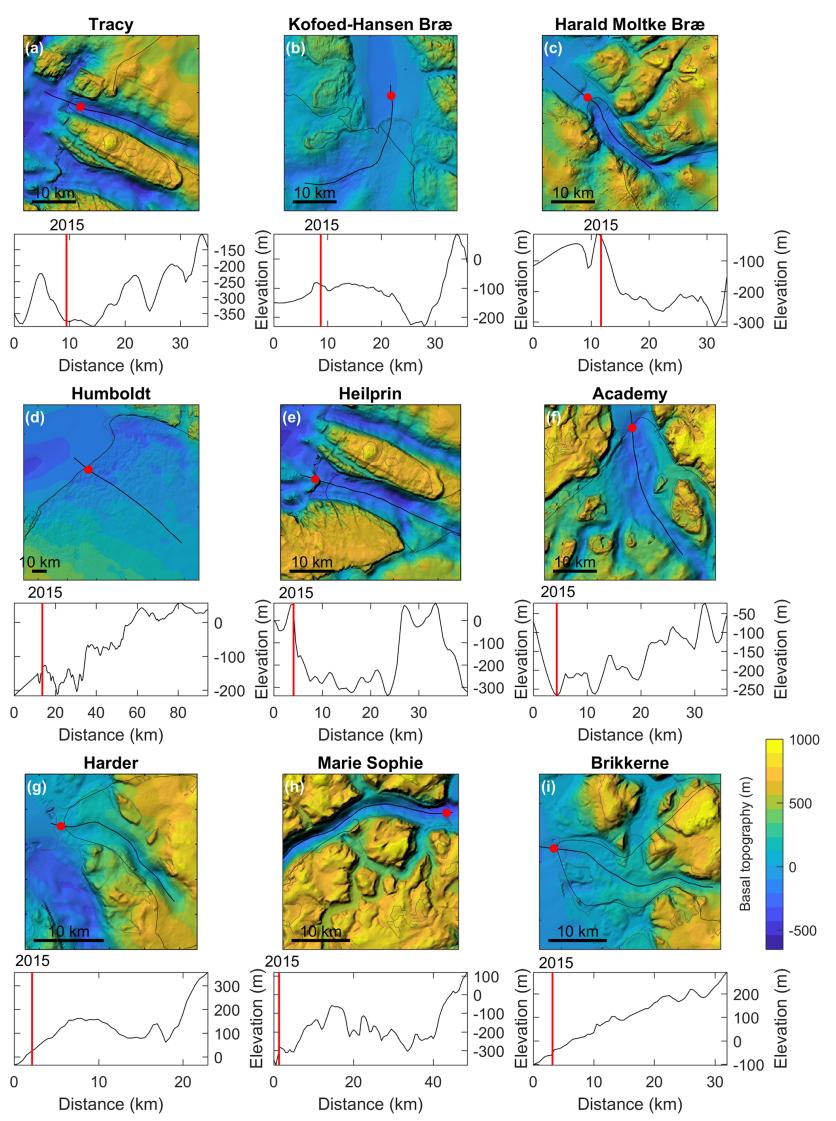

Figure 9. Basal topography from Operation IceBridge BedMachine v3 (Morlighem et al., 2017) beneath nine study glaciers with grounded termini in northern Greenland. Red points represent the position of the terminus/grounding line at each glacier from our most recent record of their terminus position (2015). Black lines are glacier centre line profiles. Profile plots show basal elevations along each glacier centre line profile, and solid red lines nearest to zero show the terminus location.

have implications for grounding-line retreat and associated instability once ice tongues collapse. Deeper bed topography ( -73 to $-1000 \mathrm{~m}$ below sea level; Fig. 10$)$ exists at floating ice tongues, and most (seven of nine) also have inlandsloping topography within $20 \mathrm{~km}$ of their grounding lines (Table 3). Unlike grounded outlet glaciers there is no obvious link to higher retreat rates or fjord widths between these glaciers. However, the current grounding-line position along glacier bed profiles appears to be associated with differences in the dynamic response of glaciers to either large calving events or entire ice tongue collapse. Grounding-line positions at Petermann Glacier, C. H. Ostenfeld Glacier, and Hagen Bræ rest on relatively flat topography (Fig. 10a, c, d), rather than retrograde slopes. In all cases, either large calving events at Petermann Glacier or entire ice tongue collapse at C. H. Ostenfeld Glacier and Hagen Brae coincided with limited glacier acceleration. In contrast, the grounding lines of glaciers draining the NEGIS (Nioghalvfjerdsfjorden
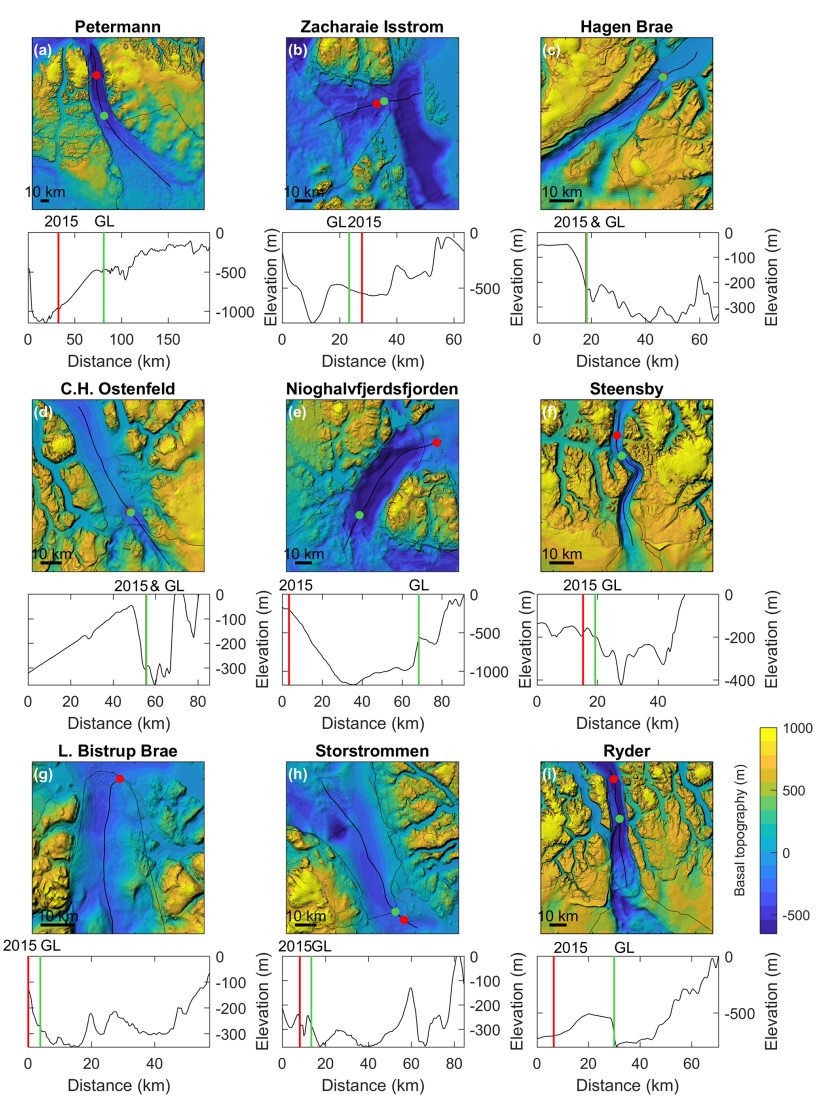

Figure 10. Basal topography from Operation IceBridge BedMachine v3 (Morlighem et al., 2017) beneath nine study glaciers which terminate in floating ice tongues in northern Greenland. Red points represent the most recent recorded terminus position (2015) from this study. Green points represent the location of the grounding line along the centre line profile from the GIMP DEM mask (Howat et al., 2014). Profile plots show basal elevations along each glacier centre line profile, where red lines closest to zero show the terminus locations, and green lines further inland show the grounding line.

and Zachariae Isstrøm) rest on steeper inland-sloping beds (Fig. 10), which correlates with their gradual ice tongue retreat and prolonged glacier acceleration. Since losing its ice tongue in 2011/2012, Zachariae Isstrøm retreated down its steep basal trough, past the recorded (nominal date of 2007 in BedMachine dataset) grounding-line position (Fig. 10b). A possible exception to this pattern of grounding-line instability on retrograde slopes is Ryder Glacier. It too has a deep basal trough $(\sim 800 \mathrm{~m}$ below sea level) $20 \mathrm{~km}$ inland of the grounding line, but further inland $(\sim 50 \mathrm{~km}$ from the terminus) it has a steep seaward-sloping bed and a large topographic ridge immediately seaward of the current groundingline position (Fig. 10c). 
Table 3. Glacier-specific factors at 18 northern Greenland study glaciers. This includes the size and percentage of each surface drainage basin below sea level, the direction of the bed slope $20 \mathrm{~km}$ inland of the grounding line (inland or seaward), and whether the fjord widens or narrows with distance inland.

\begin{tabular}{|c|c|c|c|c|c|c|c|c|}
\hline & & Northern Greenland & Drainage basin & $\%$ of drainage basin & Inland bed slope & Seaward bed slope & Widening fjord & Narrowing fjord \\
\hline \multirow{9}{*}{ 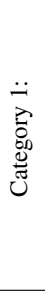 } & \multirow{9}{*}{ 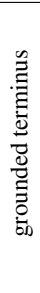 } & Tracy & 3176 & 3.6 & $\mathrm{X}$ & & & $\mathrm{X}$ \\
\hline & & Kofoed-Hansen Bræ & $\mathrm{b}$ & $\mathrm{b}$ & $\mathrm{X}$ & & $\mathrm{X}$ & \\
\hline & & Harald Moltke Bræ & 666 & 17 & $\mathrm{X}$ & & & $\mathrm{X}$ \\
\hline & & Humboldt & 51815 & 27 & $\mathrm{X}$ & & Does not ter & inate in fjord \\
\hline & & Heilprin & 6593 & 2.9 & $\mathrm{X}$ & & $\mathrm{X}$ & \\
\hline & & Academy & a & a & & $\mathrm{X}$ & $\mathrm{X}$ & \\
\hline & & Harder & 792 & 0.2 & & $\mathrm{X}$ & & $\mathrm{X}$ \\
\hline & & Marie-Sophie & 2567 & 6.8 & & $\mathrm{X}$ & $\mathrm{X}$ & \\
\hline & & Brikkerne & 929 & 2.3 & & $\mathrm{X}$ & & $\mathrm{X}$ \\
\hline \multirow{9}{*}{ 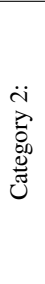 } & \multirow{9}{*}{ 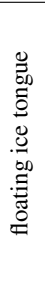 } & Petermann & 60093 & 67 & $\mathrm{X}$ & & $\mathrm{X}$ & \\
\hline & & Zachariae Isstrøm & $257542^{\mathrm{b}}$ & 54 & $\mathrm{X}$ & & $\mathrm{X}$ & \\
\hline & & Hagen Bræ & $30250^{\mathrm{a}}$ & 20 & & $\mathrm{X}$ & $\mathrm{X}$ & \\
\hline & & C. H. Ostenfeld & 11013 & 1.5 & $\mathrm{X}$ & & & $\mathrm{X}$ \\
\hline & & Nioghalvfjerdsfjorden & b & $\mathrm{b}$ & $\mathrm{X}$ & & & $\mathrm{X}$ \\
\hline & & Steensby & 3356 & 4.2 & $\mathrm{X}$ & & & $\mathrm{X}$ \\
\hline & & L. Bistrup Bræ & 26660 & 4.4 & $\mathrm{X}$ & & $\mathrm{X}$ & \\
\hline & & Storstrømmen & b & $\mathrm{b}$ & $\mathrm{X}$ & & $\mathrm{X}$ & \\
\hline & & Ryder & 36384 & 40 & & $\mathrm{X}$ & $\mathrm{X}$ & \\
\hline
\end{tabular}

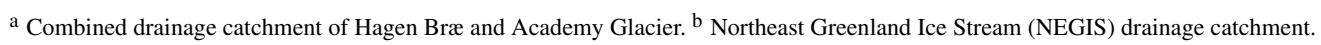

\section{Discussion}

\subsection{Timing of glacier change between 1948 and 2016}

Decadal terminus changes at all 18 study glaciers (Fig. 4) showed a transition from slow low-magnitude advance and retreat (averaging $+72 \mathrm{~m} \mathrm{a}^{-1}$ ) between 1948 and 1995 to rapid high-magnitude retreat (averaging $-445 \mathrm{ma}^{-1}$ ) between 1996 and 2015. The latter period included the onset of steady retreat at most grounded outlet glaciers in northern Greenland and the occurrence of large, rapid retreat events at floating-ice-tongue glaciers (Fig. 5). While this switch from minimal terminus change/advance to more rapid retreat is perhaps similar to the cyclic behaviour of tidewater glaciers (Meier and Post, 1987; Pfeffer, 2007), it is unlikely that this pattern of widespread retreat is driven by internal factors alone (e.g. Nick et al., 2007). Instead, climateinduced dynamic thinning at outlet glacier margins (Khan et al., 2014; Pritchard et al., 2009) may have been the initial forcing for increased glacier retreat rates in northern Greenland. The switch to terminus retreat in the 1990s was coincident with increased air and ocean temperatures across the GrIS (e.g. Box et al., 2009; Hanna et al., 2008; Luckman et al., 2006), ice marginal thinning $(<2000 \mathrm{~m}$ elevation) since the 1990s (Abdalati et al., 2001; van den Broeke et al., 2016; Krabill et al., 2000), and Arctic-wide increased retreat rates (Carr et al., 2017b; Moon and Joughin, 2008; Jensen et al., 2016). Previous studies in northern Greenland have suggested that climate ocean forcing at glacier termini- i.e. increased air temperatures, reduced sea ice concentration, and ocean-warming-induced basal melt - triggered dynamic thinning, retreat, and mass loss from outlet glacier margins (Khan et al., 2014; Reeh et al., 2001; Rignot et al., 2001; Rignot and Steffen, 2008). Here, we do not assess in detail the climate ocean forcing mechanisms that may have influenced recent terminus change behaviour in northern Greenland, partly due to lack of data and partly because the focus of this paper is on glacier dynamics and their interaction with topography. However, we note that surface thinning preceded rapid terminus retreat at many northern Greenland glaciers (Figs. 6 and 7). Therefore, we suggest that dynamic thinning could have been the initial process that accelerated glacier retreat in northern Greenland since the 1990s (cf. Felikson et al., 2017; Nick et al., 2009; Price et al., 2011). However, in line with tidewater glacier cyclic behaviour, it is likely that after an initial change in dynamics at the terminus triggered by climate forcing, fjord width and depth become more important controls (see Sect. 4.3) on the duration and magnitude of retreat at individual glaciers (Benn et al., 2007; Catania et al., 2018; MacGregor et al., 2012).

\subsection{Dynamic glacier response to terminus change}

Our analysis of termini behaviour shows that the dynamic glacier response (acceleration and thinning) to a frontal position change is highly dependent on whether the terminus is grounded or the glacier terminates in a floating ice tongue (Benn et al., 2007). Informed by our change point analy- 
sis, we infer two dominant calving behaviours in northern Greenland based on these terminus types: (1) low-magnitude continuous calving events/terminus retreat at grounded outlet glaciers and (2) large episodic tabular calving events at glaciers with floating ice tongues. Independent of these styles (continuous vs. episodic), calving in both categories of terminus type is influenced by the velocity structure of the glacier, and ice velocity itself is sensitive to changes in terminus position and alterations to the force balance, i.e. decreased basal/lateral resistance and increased driving stress (Benn et al., 2007). In the previous section, we hypothesised that increased thinning at the glacier terminus $(\sim 1990 \mathrm{~s})$ may have initiated enhanced retreat and accelerated terminus velocities in the following 2 decades (1996-2015), similar to other regions of the ice sheet (e.g. Luckman et al., 2006; McFadden et al., 2011; Moon and Joughin, 2008). Such thinning could cause downstream increases in velocity, which stretches the ice, promotes crevasse-propagationinduced calving, and propagates the dynamic response (i.e. acceleration) up-glacier. However, the coarse resolution of our elevation change datasets limits our ability to deduce the initial cause of accelerated retreat, so instead we focus on the trends in dynamic glacier changes (acceleration and thinning) after the onset of retreat.

Following an assumed initial change in terminus conditions $(\sim 1990 \mathrm{~s})$, outlet glaciers in northern Greenland that are grounded at their terminus underwent prolonged periods of steady terminus retreat (on average $-150 \mathrm{~m} \mathrm{a}^{-1}$ ), which usually lasted for 2-3 decades (Fig. 5). Like grounded outlet glaciers elsewhere, e.g. Helheim and Kangerdlugssuaq (Howat et al., 2005, 2007, 2008) and in west Greenland (McFadden et al., 2011), periods of steady and continuous retreat at grounded-terminus outlet glaciers in northern Greenland were accompanied by increased annual ice velocities (27\%$110 \%$ ) and dynamic thinning (Fig. 6). From this dynamic response we suggest that continuous calving and retreat, and the associated reduction in resistive stresses at the terminus, substantially altered the force balance by increasing longitudinal stretching and driving stress. This prolonged stress perturbation at the terminus of most grounded outlet glaciers in northern Greenland allowed acceleration and thinning to propagate inland and continue for a longer period as most glaciers may have not reached a stable geometry (McFadden et al., 2011; Nick et al., 2009: Sect. 4.3).

In contrast, terminus changes at most glaciers with floating ice tongues were characterised by short-lived ( $<6$ years), significantly higher-magnitude retreat events that averaged $-4536 \mathrm{~m} \mathrm{a}^{-1}$ (after $\sim 1990 \mathrm{~s}$ ). These high-magnitude retreat events were often due to the calving of large tabular icebergs, initiated by rift propagation (e.g. MacGregor et al., 2012). However, these large calving events were followed by minimal and/or short-lived increases in annual velocity, and shortterm increases in ice surface thinning rates (Fig. 7). From these velocity records we infer that in most cases large calving events appeared not to substantially perturb the glacier force balance either by increasing longitudinal stretching or by driving stresses on grounded ice, which would lead to annual acceleration (Fig. 7). This was particularly the case at Petermann Glacier, Hagen Bræ, and C. H. Ostenfeld Glacier, in response to ice tongue collapse or large calving events. This contrasts with the behaviour of ice-tongue-terminating glaciers elsewhere in Greenland (e.g. Joughin et al., 2004, 2008) and glaciers draining into Antarctic ice shelves (e.g. Scambos et al., 2004), which instead showed prolonged acceleration and dynamic thinning following the loss of substantial parts of floating ice. At some glaciers short-lived acceleration was followed by reduced retreat and deceleration (e.g. Hagen Bræ), which represents a rapid re-adjustment at the terminus, and suggests that calving at floating-ice-tongue glaciers in northern Greenland limits the dynamic glacier response to large calving events. This could be due to limited lateral resistance provided by floating ice tongues (Sect. 4.3).

However, Zachariae Isstrøm was a notable exception to this pattern. At Zachariae Isstrøm, sustained annual calving was accompanied by a longer period of glacier acceleration and thinning (Fig. 7b). This is comparable to the behaviour of grounded outlet glaciers in northern Greenland and ice-tongue-terminating glaciers elsewhere (e.g. Jakobshavn Isbræ: Joughin et al., 2004, 2008). In this case, continuous retreat is likely to have gradually reduced resistive forces (i.e. backstress) acting on inland grounded ice, causing higher-magnitude and prolonged flow acceleration. Apart from Zachariae Isstrøm, our data show that outlet glaciers in northern Greenland have been largely insensitive to either entire ice tongue loss (C. H. Ostenfeld Glacier, Steensby Glacier, and Hagen Bræ) or large iceberg calving events (Petermann, Nioghalvfjerdsfjorden). Thus, despite some similarities (e.g. Zachariae Isstrøm to grounded behaviour), region-wide glacier behaviour in northern Greenland appears dependent on whether the terminus is grounded or floating, due to their calving nature and dynamic response to perturbations of their termini. This highlights the need to consider terminus type when assessing the long-term response of outlet glaciers to changes at their terminus.

\subsection{Influence of glacier geometry}

While climate ocean forcing may have triggered a change in glacier dynamics at the terminus of outlet glaciers in northern Greenland (e.g. Khan et al., 2014; Reeh et al., 2001), glacier geometry (e.g. width and depth of fjords) may have determined the duration and extent of the resultant retreat. Indeed, variations in basal topography and fjord width have been previously identified as an important control on the dynamic response of glaciers in many regions of the GrIS (e.g. Carr et al., 2013, 2017b; Howat and Eddy, 2011; McFadden et al., 2011; Millan et al., 2018; Thomas et al., 2009). Collectively these factors could explain differences between groundedterminus and floating-ice-tongue glaciers (McFadden et al., 2011), as well as individual glacier variability. 
Calving from grounded outlet margins is controlled by both basal and lateral drag, and both reduce as a glacier retreats into a deeper and wider fjord (Benn et al., 2007). At grounded outlet glaciers in northern Greenland, prolonged acceleration and thinning following retreat suggests that these glaciers were still adjusting to terminus change by the end of the study period in 2015. This is likely due to deep basal topography ( $>200 \mathrm{~m}$ below sea level) and retrograde bed slopes ( $\sim 20 \mathrm{~km}$ of their grounding zones) beneath most grounded-terminus glaciers (Fig. 9). We suggest grounded-terminus retreat into deeper water contributed to (i) buoyancy driven feedbacks, as the ice thinned to flotation (van der Veen, 1996); (ii) the penetration of basal crevasses through the full ice thickness (van der Veen, 1998, 2007); and (iii) subsequent enhanced rates of calving and continued retreat (e.g. Joughin et al., 2008). Our results showed that grounded outlet glaciers which retreated into deeper fjords had higher retreat rates (e.g. Tracy, Harald Moltke Bræ, and Heilprin), than those with shallower basal troughs (e.g. Academy and Marie-Sophie). The former three glaciers also appear to be retreating downslope from topographic highs at the edge of their fjords (Fig. 9a, c, e).

Unlike grounded termini, floating ice tongues predominantly provide resistive stresses through their contact with the lateral fjord margins. Consequently, lateral resistive stresses are the main control on the glacier force balance and driving stresses, and hence the impact of terminus retreat on inland ice dynamics. Our data have shown variability in glacier response to ice tongues loss (Fig. 7), and we suggest that this could be due to differences in the lateral resistive the floating ice tongue provides when it is in place. Once the ice tongue has entirely collapsed, the terminus becomes grounded, at which point basal drag becomes an important control, and basal topography at and immediately inland of the grounding line becomes more significant.

At most glaciers with floating ice tongues in northern Greenland, the minimal dynamic response to ice tongue retreat and/or collapse (Fig. 7) may be due to limited lateral resistance provided by their floating ice tongues. In particular, C. H. Ostenfeld Glacier and Hagen Bræ have heavy rifting along their shear margins and appear relatively unconfined by their fjord walls and weakly attached to the grounded terminus (Fig. 11b, c). Indeed, both glaciers showed no significant increase in flow speeds following large calving events. This suggests that, in both cases, the buttressing provided by the tongues was minimal, and large ice tongue retreats caused a limited change in the inland force balance. Alternatively, Steensby Glacier showed some acceleration $(\sim 25 \%)$ following ice tongue retreat, which could be due to both a greater loss of lateral resistive stresses from a well-confined ice tongue and retreat past a narrower sinuous section of the fjord (Fig. 11a).

As well as the lack of resistive stress provided by their ice tongues, the limited response of Hagen Bræ and C. H. Ostenfeld Glacier to terminus retreat (Fig. 7) may result from their basal topography: following retreat, both grounding lines retreated into shallow water (Fig. 10). This may have suppressed retreat rates, as it reduces grounding-line thickness and therefore discharge. In turn, this would reduce the impact on inland ice velocities and surface thinning rates (Vieli and Nick, 2011). The flat sections of basal topography beneath the grounding lines of Petermann Glacier and Nioghalvfjerdsfjorden may also control their future response to ice tongue collapse, as their grounding lines would need to retreat $\sim 20 \mathrm{~km}$ inland to sit on a retrograde slope (Fig. 8b, g). In contrast, ice tongue collapse at Zachariae Isstrøm was followed by continued acceleration, retreat, and more dramatic thinning (Fig. 7b). Here, the deep retrograde bed slope that extends $\sim 20 \mathrm{~km}$ inland of the grounding line is likely responsible for continued retreat (Khan et al., 2014; Mouginot et al., 2015). Retreat into deeper water gradually reduced buttressing forces and caused continuous glacier acceleration and surface thinning following ice tongue collapse, similar to Jakobshavn Isbræ (Vieli and Nick, 2011).

\subsection{Glacier surging}

Surge-type behaviour has been previously documented at several outlet glaciers in northern Greenland (e.g. Hill et al., 2017; Rignot et al., 2001; Weidick et al., 1994), but detailed evidence for surging is rare. Here we briefly discuss how the surge nature of several glaciers in northern Greenland may have altered their dynamic behaviour independent of their terminus type.

Our results provide further evidence for the presence of three surge-type glaciers in northern Greenland (Storstrømmen, L. Bistrup Bræ, and Harald Moltke Bræ). This is based on the following characteristics: (1) substantial periods of glacier advance $\left(>90 \mathrm{~m} \mathrm{a}^{-1}\right)$ followed by retreat during the study period, (2) accelerated ice flow coincident with periods of advance, and (3) surface thickening inland and thinning at the terminus position indicative of a quiescent surge phase. Both Storstrømmen and L. Bistrup Bræ have floating ice tongues which began advancing in the 1970s (Reeh et al., 1999) and continued until 1985 at Storstrømmen and 1998 at L. Bistrup Bræ (Fig. 5). While velocity and surface elevation change datasets do not cover this period, dynamic changes later on (1992-2016; Fig. 8) were indicative of quiescence (Abdalati et al., 2001; Csatho et al., 2014; Thomas et al., 2009). In this respect, these glaciers have behaved differently to the majority of glaciers in the region with floating ice tongues, i.e. thickening and deceleration inland, and thinning and acceleration at the terminus (Fig. 8). In northwest Greenland, Harald Moltke Bræ has been previously considered surge type. Here we record an additional surge event from 2013 to 2014, based on high-magnitude acceleration $\left(\sim 1000 \mathrm{~m} \mathrm{a}^{-1}\right)$ and glacier advance $(0.8 \mathrm{~km}$; Fig. $6 \mathrm{c})$. This glacier fits the conventional definition of surging, i.e. a short active phase, which included an order-of-magnitude increase in velocity. However, it has a short surge cycle ( $<10$ years) 

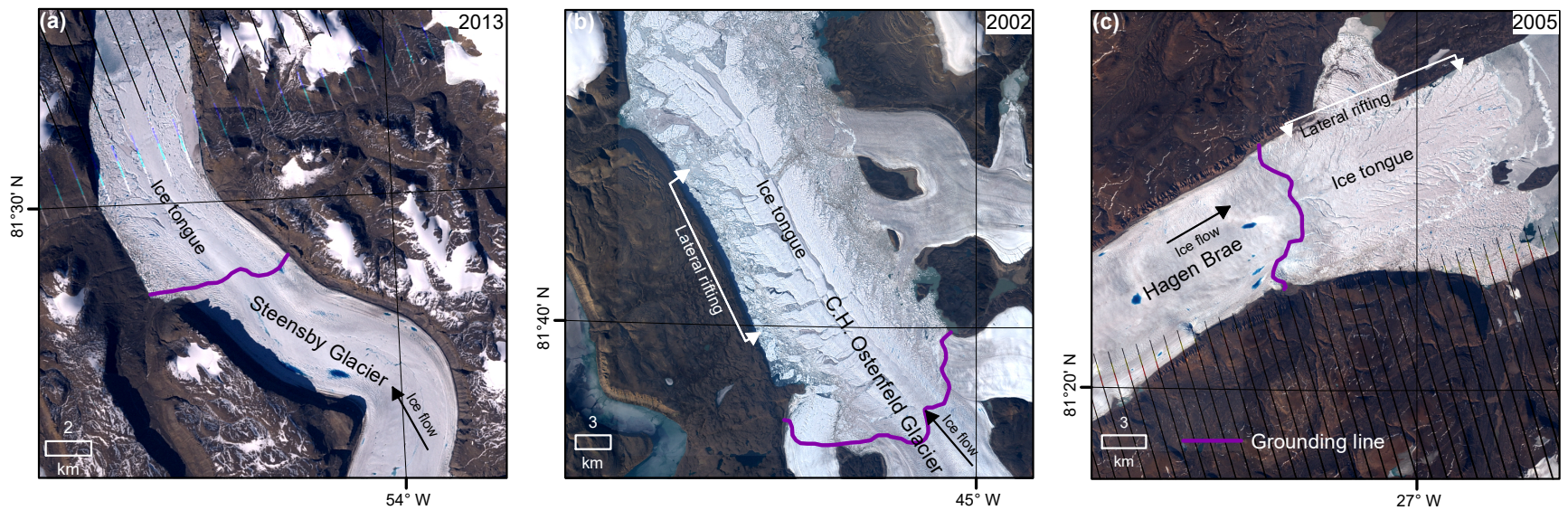

Figure 11. Landsat imagery of three glaciers which terminate in floating ice tongues in northern Greenland before their ice tongue collapse. (a) Steensby Glacier in 2013, (b) C. H. Ostenfeld Glacier in 2002, (c) Hagen Bræ in 2005. Purple lines denote the location of the grounding line.

compared to most other glaciers in the Arctic, and it underwent overall retreat from the late 1980s to 2015 (Fig. 5). This suggests that, despite short-lived surge events, recent climate ocean forcing may be altering its cyclical behaviour.

Finally, we draw attention to Ryder Glacier as it appears to be behaving dissimilarly to the rest of our study glaciers in northern Greenland. It too has been referred to as surge type in the past (Joughin et al., 1996, 1999; Rignot et al., 2001) and has shown some surge-like behaviour during our study period (1948-2015): several cycles of advance ( $\sim 7$ years) and retreat ( 2 years), and some acceleration during advance. Additionally, previous studies have also identified near-terminus thinning (2-4 $\mathrm{m} \mathrm{a}^{-1}:$ 1997-1999) and, at $\sim 50 \mathrm{~km}$ inland, a similar magnitude of thickening ( $\mathrm{Ab}-$ dalati et al., 2001), which is indicative of the quiescent phase of surge-type glaciers (e.g. Kamb et al., 1985; Meier and Post, 1969; Sharp, 1988). However, the behaviour of Ryder Glacier appears to be more characteristic of a tidewater glacier cycle, which may be controlled by basal topography. In contrast to the role of basal topography at most other outlet glaciers in northern Greenland (i.e. unstable retreat down inland-sloping beds), a large basal ridge (Fig. 10i) or terminal moraine/moraine shoal at Ryder Glacier may have promoted periods of glacier advance (Alley, 1991; Nick et al., 2007; Powell, 1990). Nevertheless, further investigation on the cyclic nature and precise controls on Ryder Glacier's dynamic behaviour is needed.

\section{Conclusions}

Outlet glaciers in northern Greenland drain $\sim 40 \%$ of the ice sheet by area but remain understudied compared to other regions of the ice sheet. We have analysed the dynamics of 18 major marine-terminating outlet glaciers in northern Greenland between 1948 and 2015. Overall, long-term glacier re- treat rates ranged from -15 to $-311 \mathrm{~m} \mathrm{a}^{-1}$ over the entire study period. Between 1948 and 1995 glaciers exhibited generally low-magnitude advance and retreat, with an average frontal position change of $+72 \mathrm{~m} \mathrm{a}^{-1}$ (advance) across the 18 study glaciers. Following this, there was a regional transition to more rapid and widespread retreat, when average frontal position change was $-445 \mathrm{~m} \mathrm{a}^{-1}$ (1995-2015). This was coincident with accelerated retreat in other regions of the ice sheet (e.g. Carr et al., 2013; Howat et al., 2008; Howat and Eddy, 2011). From 1996 to 2015, most glaciers also experienced accelerated ice flow and increased dynamic thinning.

While increased retreat rates from the mid-1990s were nearly ubiquitous, we observe distinct differences in glacier behaviour depending on whether the terminus is grounded or floating. Three factors play a role in the dynamic behaviour of these two types of glacier: (i) different methods of calving (i.e. continuous low-magnitude calving vs. large episodic calving), (ii) differences in resistive stresses at the terminus, and (iii) glacier geometry. Continuous retreat into deep fjords at grounded-terminus glaciers led to a greater reduction in basal/lateral resistive stresses and caused high-magnitude acceleration and dynamic thinning. In contrast, large episodic calving events from unconfined ice tongues that provided little lateral resistance meant that most glaciers with floating ice tongues appear dynamically insensitive to the retreat of their terminus. We note there are exceptions: continuous ice tongue retreat at Zachariae Isstrøm caused prolonged acceleration and thinning, and several glaciers with ice tongues went through cycles of advance and retreat during the study record (e.g. Ryder Glacier). At Zachariae Isstrøm this can be explained by the method of glacier calving (continuous rather than episodic) and a deep wide fjord that promoted unstable retreat. Glacier advance can be explained by surging or topographic controls which allow cyclic advance and retreat. We provide further evidence for surging at three glaciers (Harald Moltke Bræ, Storstrømmen and L. Bistrup Bræ) in north- 
ern Greenland and an explanation for the cyclic behaviour of Ryder Glacier, which is likely related to topographic controls (e.g. moraine shoal), that allowed the re-advance of the terminus. While we have shown that northern Greenland has begun to undergo rapid dynamic change over the last 2 decades (1996-2015), we highlight variability between individual glaciers and the importance of considering terminus type and glacier geometry (basal topography, fjord width, and ice tongue confinement) when considering future glacier response to climate change across this region of the ice sheet. Currently, ice tongue retreat does not appear to substantially affect inland ice dynamics. However, once these glaciers become grounded, they may accelerate, thin, and increase the volume of grounded ice discharge into the ocean.

Data availability. Shapefiles of frontal positions for all 18 outlet glaciers in this study between 1948 and 2015 are freely available on request to the corresponding author. All other data sources - including satellite imagery, historical maps, surface elevation change, annual velocity, climate and ocean, and topographic data - are already available online. The sources of each of these datasets are given in the text (see Sect. 2.1, 2.2.1, 2.3 and 2.4) and in the Supplement.

Supplement. The supplement related to this article is available online at: https://doi.org/10.5194/tc-12-3243-2018-supplement.

Author contributions. The initial project was designed by all authors, and EAH led the data analysis and interpretation, with comments throughout from all authors. EAH led the manuscript writing, and all authors contributed towards the editing of the manuscript and figures.

Competing interests. The authors declare that they have no conflict of interest.

Acknowledgements. This work was supported by a doctoral studentship award to Emily A. Hill at Newcastle University, UK, from the IAPETUS Natural Environment Research Council Doctoral Training Partnership (grant number: NE/L002590/1). We thank the ESA for granting access to SPOT-1 data (project ID: 32435). We are also grateful for Corona imagery which was digitised on request to the US Geological Survey. We acknowledge several free datasets used in this work. Historical map charts were made available from the Polar Geospatial Centre and the Perry-Castañeda Library at the University of Texas at Austin. We are grateful for Cryosat and ESA surface elevation change data, and Sentinel annual Greenland-wide velocity maps made freely available as part of the ESA Greenland Climate Change Initiative. MEaSUREs velocity maps (Joughin et al., 2010) and IceBridge BedMachine v3 (Morlighem et al., 2017) are available from the National Snow and Ice Data Centre (NSIDC). Landsat imagery were acquired from the US Geological Survey. We are extremely grateful to the editor of this manuscript -
Andreas Vieli - and to three anonymous reviews whose comments led to improvements in both the content and clarity.

Edited by: Andreas Vieli

Reviewed by: three anonymous referees

\section{References}

Abdalati, W., Krabill, W., Frederick, E., Manizade, S., Martin, C., Sonntag, J., Swift, R., Thomas, R., Wright, W., and Yungel, J.: Outlet glacier and margin elevation changes: Near-coastal thinning of the Greenland ice sheet, J. Geophys. Res., 106, 33729, https://doi.org/10.1029/2001JD900192, 2001.

Alley, R. B.: Sedimentary processes may cause fluctuations of tidewater glaciers, Ann. Glaciol., 15, 119-124, 1991.

Amundson, J. M., Fahnestock, M., Truffer, M., Brown, J., Lüthi, M. P., and Motyka, R. J.: Ice mélange dynamics and implications for terminus stability, Jakobshavn Isbrse, Greenland, J. Geophys. Res.-Earth, 115, 1-12, https://doi.org/10.1029/2009JF001405, 2010.

Benn, D. I., Warren, C. R., and Mottram, R. H.: Calving processes and the dynamics of calving glaciers, Earth-Science Rev., 82, 143-179, https://doi.org/10.1016/j.earscirev.2007.02.002, 2007.

Bevan, S. L., Luckman, A. J., and Murray, T.: Glacier dynamics over the last quarter of a century at Helheim, Kangerdlugssuaq and 14 other major Greenland outlet glaciers, The Cryosphere, 6, 923-937, https://doi.org/10.5194/tc-6-923-2012, 2012.

Box, J. E. and Decker, D. T.: Greenland marine-terminating glacier area changes: 2000-2010, Ann. Glaciol., 52, 91-98, https://doi.org/10.3189/172756411799096312, 2011.

Box, J. E., Yang, L., Bromwich, D. H., and Bai, L.S. L.-S.: Greenland Ice Sheet Surface Air Temperature Variability: 1840-2007, J. Climate, 22, 4029-4049, https://doi.org/10.1175/2009jcli2816.1, 2009.

Bunce, C., Carr, J. R., Nienow, P. W., Ross, N., and Killick, R.: Ice front change of marine-terminating outlet glaciers in northwest and southeast Greenland during the 21 st century, J. Glaciol., 113, https://doi.org/10.1017/jog.2018.44, 2018.

Carr, J. R., Vieli, A., and Stokes, C.: Influence of sea ice decline, atmospheric warming, and glacier width on marine-terminating outlet glacier behavior in northwest Greenland at seasonal to interannual timescales, J. Geophys. Res.-Earth, 118, 1210-1226, https://doi.org/10.1002/jgrf.20088, 2013.

Carr, J. R., Stokes, C., and Vieli, A.: Recent retreat of major outlet glaciers on Novaya Zemlya, Russian Arctic, influenced by fjord geometry and sea-ice conditions, J. Glaciol., 60, 155-170, https://doi.org/10.3189/2014JoG13J122, 2014.

Carr, J. R., Vieli, A., Stokes, C. R., Jamieson, S. S. R., Palmer, S. J., Christoffersen, P., Dowdeswell, J. A., Nick, F. M., Blankenship, D. D., and Young, D. A.: Basal topographic controls on rapid retreat of Humboldt Glacier, northern Greenland, J. Glaciol., 61, 137-150, https://doi.org/10.3189/2015JoG14J128, 2015.

Carr, J. R., Bell, H., Killick, R., and Holt, T.: Exceptional retreat of Novaya Zemlya's marine-terminating outlet glaciers between 2000 and 2013, The Cryosphere, 11, 2149-2174, https://doi.org/10.5194/tc-11-2149-2017, 2017a. 
Carr, J. R., Stokes, C. R., and Vieli, A.: Threefold increase in marine-terminating outlet glacier retreat rates across the Atlantic Arctic: 1992-2010, Ann. Glaciol., 58, 72-91, 2017b.

Catania, G. A., Stearns, L. A., Sutherland, D. A., Fried, M. J., Bartholomaus, T. C., Morlighem, M., Shroyer, E., and Nash, J.: Geometric Controls on Tidewater Glacier Retreat in Central Western Greenland, J. Geophys. Res.-Earth, 123, 2024-2038, https://doi.org/10.1029/2017JF004499, 2018.

Church, J. A., Clark, P. U., Cazenave, A., Gregory, J. M., Jevrejeva, S., Levermann, A., Merrifield, M. A., Milne, G. A., Nerem, R., Nunn, P. D., Payne, A. J., Pfeffer, W. T., Stammer, D., and Unnikrishnan, A. S.: Sea level change, Climate Change 2013, Physical Science Basis, Contribution Working Group I to Fifth Assessment Report of the Intergovernmental Panel on Climate Change, 1137-1216, https://doi.org/10.1017/CB09781107415315.026, 2013.

Cook, S., Rutt, I. C., Murray, T., Luckman, A., Zwinger, T., Selmes, N., Goldsack, A., and James, T. D.: Modelling environmental influences on calving at Helheim Glacier in eastern Greenland, The Cryosphere, 8, 827-841, https://doi.org/10.5194/tc-8-827-2014, 2014.

Csatho, B. M., Schenk, A. F., van der Veen, C. J., Babonis, G., Duncan, K., Rezvanbehbahani, S., van den Broeke, M. R., Simonsen, S. B., Nagarajan, S., and van Angelen, J. H.: Laser altimetry reveals complex pattern of Greenland Ice Sheet dynamics, P. Natl. Acad. Sci. USA, 111, 18478-18483, https://doi.org/10.1073/pnas.1411680112, 2014.

Enderlin, E. M., Howat, I. M., and Vieli, A.: High sensitivity of tidewater outlet glacier dynamics to shape, The Cryosphere, 7 , 1007-1015, https://doi.org/10.5194/tc-7-1007-2013, 2013.

Enderlin, E. M., Howat, I. M., Jeong, S., Noh, M. J., Van Angelen, J. H., and Van Den Broeke, M. R.: An improved mass budget for the Greenland ice sheet, Geophys. Res. Lett., 41, 866-872, https://doi.org/10.1002/2013GL059010, 2014.

Felikson, D., Bartholomaus, T. C., Catania, G. A., Korsgaard, N. J., Kjær, K. H., Morlighem, M., Noël, B., Van Den Broeke, M., Stearns, L. A., Shroyer, E. L., Sutherland, D. A., and Nash, J. D.: Inland thinning on the Greenland ice sheet controlled by outlet glacier geometry, Nat. Geosci., 10, 366-369, https://doi.org/10.1038/ngeo2934, 2017.

Fettweis, X., Franco, B., Tedesco, M., van Angelen, J. H., Lenaerts, J. T. M., van den Broeke, M. R., and Gallée, H.: Estimating the Greenland ice sheet surface mass balance contribution to future sea level rise using the regional atmospheric climate model MAR, The Cryosphere, 7, 469-489, https://doi.org/10.5194/tc7-469-2013, 2013.

Franco, B., Fettweis, X., Erpicum, M., and Nicolay, S.: Present and future climates of the Greenland ice sheet according to the IPCC AR4 models, Clim. Dynam., 36, 1897-1918, https://doi.org/10.1007/s00382-010-0779-1, 2011.

Hanna, E., Huybrechts, P., Steffen, K., Cappelen, J., Huff, R., Shuman, C., Irvine-Fynn, T., Wise, S., and Griffiths, M.: Increased runoff from melt from the Greenland Ice Sheet: A response to global warming, J. Climate, 21, 331-341, https://doi.org/10.1175/2007JCLI1964.1, 2008.

Hill, E. A., Carr, J. R., and Stokes, C. R.: A Review of Recent Changes in Major Marine-Terminating Outlet Glaciers in Northern Greenland, Front. Earth Sci., 4, 1-23, https://doi.org/10.3389/feart.2016.00111, 2017.
Holland, D. M., Thomas, R. H., de Young, B., Ribergaard, M. H., and Lyberth, B.: Acceleration of Jakobshavn Isbræ triggered by warm subsurface ocean waters, Nat. Geosci., 1, 659-664, https://doi.org/10.1038/ngeo316, 2008.

Howat, I. M. and Eddy, A.: Multi-decadal retreat of Greenland's marine-terminating glaciers, J. Glaciol., 57, 389-396, https://doi.org/10.3189/002214311796905631, 2011.

Howat, I. M., Joughin, I., Tulaczyk, S., and Gogineni, S.: Rapid retreat and acceleration of Helheim Glacier, east Greenland, Geophys. Res. Lett., 32, 1-4, https://doi.org/10.1029/2005GL024737, 2005.

Howat, I. M., Joughin, I., and Scambos, T. A.: Rapid changes in ice discharge from Greenland outlet glaciers, Science, 315, 15591561, https://doi.org/10.1126/science.1138478, 2007.

Howat, I. M., Joughin, I., Fahnestock, M., Smith, B. E., and Scambos, T. A.: Synchronous retreat and acceleration of southeast Greenland outlet glaciers 20000-06: Ice dynamics and coupling to climate, J. Glaciol., 54, 646-660, https://doi.org/10.3189/002214308786570908, 2008.

Howat, I. M., Negrete, A., and Smith, B. E.: The Greenland Ice Mapping Project (GIMP) land classification and surface elevation data sets, The Cryosphere, 8, 1509-1518, https://doi.org/10.5194/tc-8-1509-2014, 2014.

Jensen, T. S., Box, J. E., and Hvidberg, C. S.: A sensitivity study of annual area change for Greenland ice sheet marine terminating outlet glaciers?: 1999-2013, J. Glaciol., 62, 72-81, https://doi.org/10.1017/jog.2016.12, 2016.

Joughin, I., Tulaczyk, S., Fahnestock, M., and Kwok, R.: A mini-surge on the Ryder Glacier, Greenland, observed by satellite radar interferometry, Science, 274, 228-230, https://doi.org/10.1126/science.274.5285.228, 1996.

Joughin, I., Fahnestock, M., Kwok, R., Gogineni, P., and Allen, C.: Ice flow of Humboldt, Petermann and Ryder Gletscher, northern Greenland, J. Glaciol., 45, 231-241, https://doi.org/10.3189/002214399793377284, 1999.

Joughin, I., Abdalati, W. and Fahnestock, M. A.: Large fluctuations in speed on Greenland's Jakobshavn Isbrae glacier, Nature, 432, 608-610, https://doi.org/10.1038/nature03130, 2004.

Joughin, I., Howat, I. M., Fahnestock, M., Smith, B., Krabill, W., Alley, R. B., Stern, H., and Truffer, M.: Continued evolution of Jakobshavn Isbrae following its rapid speedup, J. Geophys. Res.Earth, 113, 1-14, https://doi.org/10.1029/2008JF001023, 2008.

Joughin, I., Smith, B. E., Howat, I. M., Scambos, T., and Moon, T.: Greenland flow variability from icesheet-wide velocity mapping, J. Glaciol., 56, 415-430, https://doi.org/10.3189/002214310792447734, 2010.

Kamb, B., Raymond, C. F., Harrison, W. D., Engelhardt, H., Echelmeyer, K. A., Humphrey, N., Brugman, M. M., and Pfeffer, T.: Glacier surge mechanism: 1982-1983 surge of Variegated glacier, Alaska, Science, 227, 469-479, https://doi.org/10.1126/science.227.4686.469, 1985.

Khan, S. A., Kjaer, K. H., Bevis, M., Bamber, J. L., Wahr, J., Kjeldsen, K. K., Bjork, A. A., Korsgaard, N. J., Stearns, L. A., van den Broeke, M. R., Liu, L., Larsen, N. K., and Muresan, I. S.: Sustained mass loss of the northeast Greenland ice sheet triggered by regional warming, Nat. Clim. Change, 4, 292-299, https://doi.org/10.1038/nclimate2161, 2014.

Khan, S. A., Aschwanden, A., Bjørk, A. A., Wahr, J., Kjeldsen, K. K., and Kjaer, K. H.: Greenland ice sheet mass balance: a review, 
Reports Prog. Phys., 78, 046801, https://doi.org/10.1088/00344885/78/4/046801, 2015.

Khvorostovsky, K. S.: Merging and Analysis of Elevation Time Series Over Greenland Ice Sheet From Satellite Radar Altimetry, IEEE T. Geosci. Remote, 50, 23-36, 2012.

Killick, R., Fearnhead, P., and Eckley, I. A.: Optimal detection of changepoints with a linear computational cost, J. Am. Stat. Assoc., 107, 1590-1598, https://doi.org/10.1080/01621459.2012.737745, 2012.

Kjeldsen, K. K., Korsgaard, N. J., Bjørk, A. A., Khan, S. A., Box, J. E., Funder, S., Larsen, N. K., Bamber, J. L., Colgan, W., van den Broeke, M., Siggaard-Andersen, M.-L., Nuth, C., Schomacker, A., Andresen, C. S., Willerslev, E., and Kjær, K. H.: Spatial and temporal distribution of mass loss from the Greenland Ice Sheet since AD 1900, Nature, 528, 396-400, https://doi.org/10.1038/nature16183, 2015.

Korsgaard, N. J., Nuth, C., Khan, S. A., Kjeldsen, K. K., Bjørk, A. A., Schomacker, A., and Kjær, K. H.: Digital elevation model and orthophotographs of Greenland based on aerial photographs from 1978-1987, Sci. Data, 3, 160032, https://doi.org/10.1038/sdata.2016.32, 2016.

Krabill, W., Abdalati, W., Frederick, E., Manizade, S., Martin, C., Sonntag, J., Swift, R., Thomas, R., Wright, W., and Yungel, J.: Greenland Ice Sheet: High-elevation balance and peripheral thinning, Science, 289, 428-430, https://doi.org/10.1126/science.289.5478.428, 2000.

Krabill, W., Hanna, E., Huybrechts, P., Abdalati, W., Cappelen, J., Csatho, B., Frederick, E., Manizade, S., Martin, C., Sonntag, J., Swift, R., Thomas, R., and Yungel, J.: Greenland Ice Sheet: Increased coastal thinning, Geophys. Res. Lett., 31, L24402, https://doi.org/10.1029/2004GL021533, 2004.

Lavielle, M.: Using penalized contrasts for the changepoint problem, Signal Process., 85, 1501-1510, https://doi.org/10.1016/j.sigpro.2005.01.012, 2005.

Lea, J. M., Mair, D. W. F., and Rea, B. R.: Instruments and Methods?: Evaluation of existing and new methods of tracking glacier terminus change, J. Glaciol., 60, 323-332, https://doi.org/10.3189/2014JoG13J061, 2014.

Luckman, A., Murray, T., de Lange, R., and Hanna, E.: Rapid and synchronous ice-dynamic changes in East Greenland, Geophys. Res. Lett., 33, 1-4, https://doi.org/10.1029/2005GL025428, 2006.

MacGregor, J. A., Catania, G. A., Markowski, M. S., and Andrews, A. G.: Widespread rifting and retreat of ice-shelf margins in the eastern Amundsen Sea Embayment between 1972 and 2011, J. Glaciol., 58, 458-466, https://doi.org/10.3189/2012JoG11J262, 2012.

McFadden, E. M., Howat, I. M., Joughin, I., Smith, B. E., and Ahn, Y.: Changes in the dynamics of marine terminating outlet glaciers in west Greenland (2000-2009), J. Geophys. Res.-Earth, 116, F02022, https://doi.org/10.1029/2010JF001757, 2011.

Meier, M. F. and Post, A.: What are glacier surges?, Can. J. Earth Sci., 6, 807-817, https://doi.org/10.1139/e69-081, 1969.

Meier, M. F. and Post, A.: Fast tidewater glaciers, J. Geophys. Res., 92, 9051, https://doi.org/10.1029/JB092iB09p09051, 1987.

Mernild, S. H., Liston, G. E., Hiemstra, C. A., and Christensen, J. H.: Greenland Ice Sheet Surface Mass-Balance Modeling in a 131-Yr Perspective, 1950-2080, J. Hydrometeorol., 11, 3-25, https://doi.org/10.1175/2009JHM1140.1, 2010.
Millan, R., Rignot, E., Mouginot, J., Wood, M., Bjørk, A. A., and Morlighem, M.: Vulnerability of Southeast Greenland Glaciers to Warm Atlantic Water From Operation IceBridge and Ocean Melting Greenland Data, Geophys. Res. Lett., 45, 2688-2696, https://doi.org/10.1002/2017GL076561, 2018.

Moon, T. and Joughin, I.: Changes in ice front position on Greenland's outlet glaciers from 1992 to 2007, J. Geophys. Res.-Earth, 113, 1-10, https://doi.org/10.1029/2007JF000927, 2008.

Moon, T., Joughin, I., Smith, B., and Howat, I.: 21st-Century Evolution of Greenland Outlet Glacier Velocities, Science, 336, 576578, https://doi.org/10.1126/science.1219985, 2012.

Morlighem, M., Rignot, E., Mouginot, J., Seroussi, H., and Larour, E.: Deeply incised submarine glacial valleys beneath the Greenland ice sheet, Nat. Geosci., 7, 18-22, https://doi.org/10.1038/ngeo2167, 2014.

Morlighem, M., Williams, C. N., Rignot, E., An, L., Arndt, J. E., Bamber, J. L., Catania, G., Chauché, N., Dowdeswell, J. A., Dorschel, B., Fenty, I., Hogan, K., Howat, I., Hubbard, A., Jakobsson, M., Jordan, T. M., Kjeldsen, K. K., Millan, R., Mayer, L., Mouginot, J., Noël, B. P. Y., O'Cofaigh, C., Palmer, S., Rysgaard, S., Seroussi, H., Siegert, M. J., Slabon, P., Straneo, F., van den Broeke, M. R., Weinrebe, W., Wood, M., and Zinglersen, K. B.: BedMachine v3: Complete Bed Topography and Ocean Bathymetry Mapping of Greenland From Multibeam Echo Sounding Combined With Mass Conservation, Geophys. Res. Lett., 44, 11051-11061, https://doi.org/10.1002/2017GL074954, 2017.

Mouginot, J., Rignot, E., Scheuchl, B., Fenty, I., Khazendar, A., Morlighem, M., Buzzi, A., and Paden, J.: Fast retreat of Zachariæ Isstrøm, northeast Greenland, Science, 350, 13571361, https://doi.org/10.1126/science.aac7111, 2015.

Murray, T., Scharrer, K., Selmes, N., Booth, A. D., James, T. D., Bevan, S. L., Bradley, J., Cook, S., Cordero Lana, L., Drocourt, Y., Dyke, L. M., Goldsack, A., Hughes, A. L., Luckman, A. J., and McGowan, J.: Extensive retreat of Greenland tidewater glaciers, 2000-2010, Arctic, Antarct. Alp. Res., 47, 1-36, https://doi.org/10.1657/AAAR0014-049, 2015.

Nagler, T., Rott, H., Hetzenecker, M., Wuite, J., and Potin, P.: The Sentinel-1 Mission: New Opportunities for Ice Sheet Observations, Remote Sens., 7, 9371-9389, https://doi.org/10.3390/rs70709371, 2015.

Nagler, T., Hauglund, K., Forsberg, R., and Engdahl, M.: Product User Guide (PUG), available at: http://maps.elie.ucl.ac.be/ CCI/viewer/download/ESACCI-LC-PUG-v2.5.pdf (last access: 1 October 2018), 2016.

Nick, F. M., van der Veen, C. J., and Oerlemans, J.: Controls on advance of tidewater glaciers: Results from numerical modeling applied to Columbia Glacier, J. Geophys. Res.-Earth, 112, 1-11, https://doi.org/10.1029/2006JF000551, 2007.

Nick, F. M., Vieli, A., Howat, I. M., and Joughin, I.: Large-scale changes in Greenland outlet glacier dynamics triggered at the terminus, Nat. Geosci., 2, 110-114, https://doi.org/10.1038/ngeo394, 2009.

Nick, F. M., Luckman, A., Vieli, A., Van Der Veen, C. J., Van As, D., Van De Wal, R. S. W., Pattyn, F., Hubbard, A. L., and Floricioiu, D.: The response of Petermann Glacier, Greenland, to large calving events, and its future stability in the context of atmospheric and oceanic warming, J. Glaciol., 58, 229-239, https://doi.org/10.3189/2012JoG11J242, 2012. 
Pfeffer, W. T.: A simple mechanism for irreversible tidewater glacier retreat, J. Geophys. Res.-Earth, 112, F03S25, https://doi.org/10.1029/2006JF000590, 2007.

Post, A.: Preliminary hydrography and historic terminal changes of Columbia Glacier, Alaska, US Geol. Surv. Hydrol. Atlas, 559 pp., 1975.

Post, A., O’Neel, S., Motyka, R. J., and Streveler, G.: A complex relationship between calving glaciers and climate, Eos T. Am. Geophys. Un., 92, 305-307, https://doi.org/10.1029/2011EO370001, 2011.

Powell, R. D.: Glacimarine processes at groundingline fans and their growth to ice-contact deltas, Geol. Soc. London, Spec. Publ., 53, 53-73, https://doi.org/10.1144/GSL.SP.1990.053.01.03, 1990.

Price, S. F., Payne, A. J., Howat, I. M., and Smith, B. E.: Committed sea-level rise for the next century from Greenland ice sheet dynamics during the past decade, P. Natl. Acad. Sci. USA, 108, 8978-8983, https://doi.org/10.1073/pnas.1017313108, 2011.

Pritchard, H. D., Arthern, R. J., Vaughan, D. G., and Edwards, L. A.: Extensive dynamic thinning on the margins of the Greenland and Antarctic ice sheets, Nature, 461, 971-975, https://doi.org/10.1038/nature08471, 2009.

Reeh, N., Mayer, C., and Miller, H.: Present and past climate control on fjord glaciations in Greenland: Implications for IRDdeposition in the sea, Geophys. Res. Lett., 26, 1039-1042, https://doi.org/10.1029/1999GL900065, 1999.

Reeh, N., Thomsen, H. H., Higgins, A. K., and Weidick, A.: Sea ice and the stability of north and northeast Greenland floating glaciers, Ann. Glaciol., 33, 474-480, https://doi.org/10.3189/172756401781818554, 2001.

Rignot, E. and Kanagaratnam, P.: Changes in the velocity structure of the Greenland Ice Sheet, Science, 311, 986-990, https://doi.org/10.1126/science.1121381, 2006.

Rignot, E. and Steffen, K.: Channelized bottom melting and stability of floating ice shelves, Geophys. Res. Lett., 35, 2-6, https://doi.org/10.1029/2007GL031765, 2008.

Rignot, E., Gogineni, S., Joughin, I., and Krabill, W.: Contribution to the glaciology of northern Greenland from satellite radar interferometry, J. Geophys. Res.-Atmos., 106, 34007-34019, https://doi.org/10.1029/2001JD900071, 2001.

Rignot, E., Box, J. E., Burgess, E., and Hanna, E.: Mass balance of the Greenland ice sheet from 1958 to 2007, Geophys. Res. Lett., 35, 1-5, https://doi.org/10.1029/2008GL035417, 2008.

Rignot, E. J., Gogineni, S. P., Krabill, W. B., and Ekholm, S.: North and Northeast Greenland Ice Discharge from Satellite Radar Interferometry, Science, 276, 934-937, https://doi.org/10.1126/science.276.5314.934, 1997.
Scambos, T. A., Bohlander, J. A., Shuman, C. A., and Skvarca, P.: Glacier acceleration and thinning after ice shelf collapse in the Larsen B embayment, Antarctica, Geophys. Res. Lett., 31, 1-4, https://doi.org/10.1029/2004GL020670, 2004.

Schwanghart, W. and Kuhn, N. J.: TopoToolbox: A set of Matlab functions for topographic analysis, Environ. Model. Softw., 25, 770-781, https://doi.org/10.1016/j.envsoft.2009.12.002, 2010.

Sharp, M.: Surging glaciers: behaviour and mechanisms, Prog. Phys. Geogr., 12, 349-370, https://doi.org/10.1177/030913338801200302, 1988.

Simonsen, S. B. and Sørensen, L. S.: Implications of changing scattering properties on Greenland ice sheet volume change from Cryosat-2 altimetry, Remote Sens. Environ., 190, 207-216, https://doi.org/10.1016/j.rse.2016.12.012, 2017.

Sørensen, L. S., Simonsen, S. B., Meister, R., Forsberg, R., Levinsen, J. F., and Flament, T.: Envisat-derived elevation changes of the Greenland ice sheet, and a comparison with ICESat results in the accumulation area, Remote Sens. Environ., 160, 56-62, https://doi.org/10.1016/j.rse.2014.12.022, 2015.

Thomas, R.: Force perturbation analysis of recent thinning and acceleration of Jakobshavn Isbrae, Greenland, J. Glaciol., 50, 5766, https://doi.org/10.3189/172756504781830321, 2004.

Thomas, R., Frederick, E., Krabill, W., Manizade, S., and Martin, C.: Recent changes on greenland outlet glaciers, J. Glaciol., 55, 147-162, https://doi.org/10.3189/002214309788608958, 2009.

van den Broeke, M. R., Enderlin, E. M., Howat, I. M., Kuipers Munneke, P., Noël, B. P. Y., van de Berg, W. J., van Meijgaard, E., and Wouters, B.: On the recent contribution of the Greenland ice sheet to sea level change, The Cryosphere, 10, 1933-1946, https://doi.org/10.5194/tc-10-1933-2016, 2016.

van der Veen, C. J.: Tidewater calving, J. Glaciol., 42, 375-385, https://doi.org/10.1179/102453311X13127324303399, 1996.

van der Veen, C. J.: Fracture mechanics approach to penetration of surface crevasses on glaciers, Cold Reg. Sci. Technol., 27, 31-47, https://doi.org/10.1016/S0165-232X(97)00022-0, 1998.

van der Veen, C. J.: Fracture propagation as means of rapidly transferring surface meltwater to the base of glaciers, Geophys. Res. Lett., 34, L01501, https://doi.org/10.1029/2006GL028385, 2007.

Vieli, A. and Nick, F. M.: Understanding and Modelling Rapid Dynamic Changes of Tidewater Outlet Glaciers: Issues and Implications, Surv. Geophys., 32, 437-458, https://doi.org/10.1007/s10712-011-9132-4, 2011.

Weidick, A., Andreasen, C., Oerter, H., and Reeh, N.: Neoglacial Glacier Changes around Storstrømmen, North-East Greenland, Polarforschung, 64, 95-108, 1994. 